\title{
Fiscal and monetary policies in complex evolving economies
}

Citation for published version (APA):

Dosi, G., Fagiolo, G., Napoletano, M., Roventini, A., \& Treibich, T. G. (2014). Fiscal and monetary policies in complex evolving economies. Maastricht University, Graduate School of Business and Economics. GSBE Research Memoranda No. 006 https://doi.org/10.26481/umagsb.2014006

Document status and date:

Published: 01/01/2014

DOI:

10.26481/umagsb.2014006

Document Version:

Publisher's PDF, also known as Version of record

\section{Please check the document version of this publication:}

- A submitted manuscript is the version of the article upon submission and before peer-review. There can be important differences between the submitted version and the official published version of record.

People interested in the research are advised to contact the author for the final version of the publication, or visit the DOI to the publisher's website.

- The final author version and the galley proof are versions of the publication after peer review.

- The final published version features the final layout of the paper including the volume, issue and page numbers.

Link to publication

\footnotetext{
General rights rights.

- You may freely distribute the URL identifying the publication in the public portal. please follow below link for the End User Agreement:

www.umlib.nl/taverne-license

Take down policy

If you believe that this document breaches copyright please contact us at:

repository@maastrichtuniversity.nl

providing details and we will investigate your claim.
}

Copyright and moral rights for the publications made accessible in the public portal are retained by the authors and/or other copyright owners and it is a condition of accessing publications that users recognise and abide by the legal requirements associated with these

- Users may download and print one copy of any publication from the public portal for the purpose of private study or research.

- You may not further distribute the material or use it for any profit-making activity or commercial gain

If the publication is distributed under the terms of Article $25 \mathrm{fa}$ of the Dutch Copyright Act, indicated by the "Taverne" license above, 


\section{Maastricht University}

Giovanni Dosi, Giorgio Fagiolo, Mauro Napoletano,

Andrea Roventini, Tania Treibich

Fiscal and Monetary Policies in Complex Evolving

Economies

RM/14/006

\section{GSBE}

Maastricht University School of Business and Economics

Graduate School of Business and Economics

P.O Box 616

NL- 6200 MD Maastricht

The Netherlands 


\title{
Fiscal and Monetary Policies in Complex Evolving Economies
}

\author{
Giovanni Dosi* Giorgio Fagiolo ${ }^{\dagger} \quad$ Mauro Napoletano ${ }^{\ddagger} \quad$ Andrea Roventini $^{\S}$ \\ Tania Treibich
}

February 25, 2014

\begin{abstract}
In this paper we explore the effects of alternative combinations of fiscal and monetary policies under different income distribution regimes. In particular, we aim at evaluating fiscal rules in economies subject to banking crises and deep recessions. We do so using an agent-based model populated by heterogeneous capital- and consumption-good firms, heterogeneous banks, workers/consumers, a Central Bank and a Government. We show that the model is able to reproduce a wide array of macro and micro empirical regularities, including stylised facts concerning financial dynamics and banking crises. Simulation results suggest that the most appropriate policy mix to stabilise the economy requires unconstrained counter-cyclical fiscal policies, where automatic stabilisers are free to dampen business cycles fluctuations, and a monetary policy targeting also employment. Instead, "discipline-guided" fiscal rules such as the Stability and Growth Pact or the Fiscal Compact in the Eurozone always depress the economy, without improving public finances, even when escape clauses in case of recessions are considered. Consequently, austerity policies appear to be in general self-defeating. Furthermore, we show that the negative effects of austere fiscal rules are magnified by conservative monetary policies focused on inflation stabilisation only. Finally, the effects of monetary and fiscal policies become sharper as the level of income inequality increases.
\end{abstract}

Keywords: agent-based model, fiscal policy, monetary policy, banking crises, income inequality, austerity policies, disequilibrium dynamics

JEL Classification: C63, E32, E6, E52, G01, G21, O4

\footnotetext{
${ }^{*}$ Corresponding author: Institute of Economics (LEM), Scuola Superiore Sant'Anna; Piazza Martiri della Libertá 33 - I-56127 PISA (Italy); E-mail address: gdosi@sssup.it.

${ }^{\dagger}$ Institute of Economics (LEM), Scuola Superiore Sant'Anna, Pisa (Italy); E-mail address: giorgio.fagiolo@sssup.it

${ }^{\ddagger}$ OFCE and Skema Business School, Sophia-Antipolis (France), and Scuola Superiore Sant’Anna, Pisa (Italy); E-mail address: mauro.napoletano@sciencespo.fr

${ }^{\S}$ Università di Verona (Italy), Scuola Superiore Sant'Anna, Pisa (Italy), and OFCE, Sophia-Antipolis (France); E-mail address: andrea.roventini@univr.it

`Maastricht University (the Netherlands), Scuola Superiore Sant'Anna, Pisa (Italy), and GREDEG CNRS, University of Nice-Sophia Antipolis (France); E-mail address: tania.treibich@gmail.com
} 


\section{Introduction}

This work investigates alternative combinations of fiscal and monetary policies in an agent-based model that naturally yields the possibility of persistent fluctuations, deep recessions and also banking crises.

Endogenous economic crises often originated by systemic failures in the banking sector are recurrent in capitalistic economies (a point already emphasised by Keynes, 1936; Kindleberger, 1986 and more specifically on financial crises by Caprio and Klingebiel, 2002 and Laeven and Valencia, 2008). These crises usually impose huge bailout costs on the public sector. ${ }^{1}$ Moreover, they also involve indirect costs, such as credit-crunch induced recessions, losses in tax revenues and high government spending. Understanding what type of fiscal and monetary policy mix has to be employed to respond to such crises, and what is the impact of fiscal rules on real economic activity and on government debt, becomes therefore crucial. At one extreme, supporters of "expansionary austerity" (e.g Alesina and Ardagna, 2010) claim that tighter constraints on public expenditure are effective in bringing public finances under control, and may even stimulate economic activity. At the other extreme, arguments rooted in the Keynesian tradition (see e.g. Krugman, 2013) and recent empirical evidence (cf. e.g. Guajardo et al., 2011; Blanchard and Leigh, 2013) stress the self-defeating character of austerity, especially in the case of a monetary union (De Grauwe and Ji, 2013). ${ }^{2}$ Within the Eurozone, fiscal rules represent a core disciplinary mechanism, but their possible perverse effects are still not well-enough documented. Tighter constraints on public finances may further depress the economy as well as increase government debt, in particular when the size of fiscal multipliers is high (i.e. during a recession, see Auerbach and Gorodnichenko, 2012, or when credit markets are under stress, cf. Ferraresi et al., 2013).

More specifically, dysfunctions in financial markets originated by banking crises and the emergence of the zero lower bound may limit the ability to conduct standard monetary policy, thus increasing the importance of fiscal policy as an effective tool to restore aggregate demand and fight unemployment (Woodford, 2011; Christiano et al., 2011; Eggertsson and Krugman, 2012). At the same time, high public deficits imposed by bank bailouts and by the costs of automatic stabilisers may lead to sovereign debt crises (Laeven and Valencia, 2008; Reinhart and Rogoff, 2009), thus partially or completely hampering the possibility of using the fiscal levers to stimulate the economy.

Indeed, one of the greatest shocks associated with the Great Recession has been upon the economic discipline itself, both in its prevalent macro theory and its conventional policy, big enough to unveil to part of the profession a "brave new world" (Blanchard et al., 2013), or more radically to some others a striking proof that "the economic crisis is the crisis of economic theory" (Kirman, 2010b). Certainly, a powerful lesson seems to be the tall requirement that the possible effects of different ensembles of macroeconomic policies should be studied in models

\footnotetext{
${ }^{1}$ In their evaluation of the state of public finances after the 2008 crisis, the IMF estimated the upfront Government financing cost to reach in some cases nearly 20\% of GDP (Cottarelli, 2009, Table 1). Considering instead 122 banking crises since 1976, Laeven and Valencia (2008) report gross fiscal costs higher than 50\% of GDP in two occasions (Argentina, 1980 and Indonesia, 1997).

${ }^{2}$ De Grauwe and Ji (2013) discuss the mechanisms leading to a self-fulfilling debt crisis. Because of investors' distrust in some eurozone countries' ability to sustain their public debt, and the liquidity uncertainties pertaining to monetary unions, a vicious circle of austerity measures and recessions is put into motion, dragging these countries into insolvency.
} 
that are able to address far-from-equilibrium dynamics and the deep crises generated by the possible endogenous generation and non-linear transmission of non-Gaussian shocks, seemingly at the root of the recent Great Recession (Ng and Wright, 2013). In that the economy should be considered as a complex evolving system, where aggregate outcomes cannot be derived from the properties of individuals' behaviours (Kirman, 1992; Colander et al., 2008). Instead, macroeconomic phenomena such as banking crises, bankruptcy cascades, domino effects, systemic risk and credit crunches endogenously emerge out of the interactions occurring between heterogeneous agents (Farmer and Foley, 2009; Kirman, 2010a; Rosser, 2011; Dosi, 2012).

To explore the above issues we expand the Keynes+Schumpeter $(\mathrm{K}+\mathrm{S})$ model (Dosi et al., 2010, 2013) to include heterogeneous banks. Our model is a bridge between Keynesian theories of demand generation and Schumpeterian theories of innovation and economic growth, with "Minskyan" financial dynamics. It describes an economy composed of heterogeneous capitaland consumption-good firms, a labour force, banks, a Government, and a Central Bank. Capitalgood firms perform $\mathrm{R} \& \mathrm{D}$ and produce heterogeneous machine tools. Consumption-good firms invest in new machines and produce a homogeneous consumption good. The latter type of enterprises finance their production and investments first with their liquid assets and, if these are not enough, they ask their bank for credit (which is more expensive than internal funds). Bank failures endogenously emerge in the model from the accumulation of loan losses on banks' balance sheets. Banking crises imply direct bailout costs on the public budget and may therefore affect the dynamics of government deficit and debt. The latter can also vary as a consequence of the change in tax revenues and unemployment subsidies over the business cycle.

Our model, rooted in the evolutionary tradition (Nelson and Winter, 1982), belongs to the growing body of literature on macroeconomic agent-based models (Tesfatsion and Judd, 2006; LeBaron and Tesfatsion, 2008). ${ }^{3}$ The microeconomic foundations of the model are "behavioural" (Akerlof, 2002): heterogeneous agents (firms, banks, etc.) behave in a "realistic" way - i.e. in line with the micro empirical evidence - and they interact without resorting to any ex ante commitment to the reciprocal consistency of their actions, thus implicitly addressing the call by Solow (2008) for genuine micro-heterogeneity.

Before studying how different macroeconomic policy mixes affect the dynamics of the economy, we empirically validate the model by showing that the statistical properties of simulated microeconomic and macroeconomic data are in line with the empirically observed ones. As its antecedents (Dosi et al., 2010, 2013), we find that the extended K+S model replicates a rather long list of macro and micro stylised facts. In particular, the current version with heterogeneous banks provides a richer description of the banking sector matching new stylized facts related to credit and banking crises. Examples include the cross-correlations between output and credit variables, and between debt and loan losses, as well as the distributional properties of bank crisis duration.

Next, we use the model to perform a battery of experiments on the interaction between fiscal and monetary policies taking into account that rules that are efficient in normal times might have

\footnotetext{
${ }^{3}$ For germane ABMs, see Verspagen (2002); Saviotti and Pyka (2008); Ciarli et al. (2010); Mandel et al. (2010); Delli Gatti et al. (2010, 2011); Ashraf et al. (2011); Gai et al. (2011); Battiston et al. (2012); Geanakoplos et al. (2012); Seppecher (2012); Dawid et al. (2014); Raberto et al. (2012, 2014); Salle et al. (2013); Lengnick (2013); Riccetti et al. (2013) and the papers in Gaffard and Napoletano (2012). See also Fagiolo and Roventini (2012) for a critical comparison of policy analysis in DSGE and agent-based models.
} 
perverse effects in times of financial instability. Such instability is inherent to the family of Basel macroprudential rules which link credit availability to banks' equity. These capital-adequacy rules act as an automatic de-stabiliser, by further amplifying the pro-cyclicality of credit. Given the long record of financial crises and the recent Great Recession, macroeconomic policy mixes ought to be studied in models that are able to repeatedly diverge away from equilibrium as empirical economies do. Evolutionary, agent-based models like ours are concerned with the emergent properties of a simulated system in which heterogeneous agents' routinised behaviours are aggregated. The evolution of the system is given by these repeated interactions, which may occur close or very far from full-employment equilibria. Our model is therefore able to account for endogenously-generated small but also large, non-Gaussian shocks that push the economy into deep recessions and crises via non-linear transmission mechanisms. In turn, such evolution gives rise to global regularities which can be statistically studied (Tesfatsion, 2001). Finally, the simulated economic systems can be used as "computational laboratories" where the effects of alternative policy rules on targeted aggregates can be tested and compared.

Simulation results show that the most appropriate macroeconomic policy mix to achieve steady long-run economic growth together with short-run stability of the economy and of the public budget requires a combination of unconstrained fiscal policy, where automatic stabilisers can fully tackle business cycle fluctuations, together with a dual-mandate monetary policy focused on both inflation and output stabilization. The introduction of fiscal rules à la Stability and Growth Pact or Fiscal Compact considerably harms the performance of the economy, while leading to persistent public deficits. This holds also when fiscal rules are supplemented by an escape clause which suspends them in case of recession. In particular, our results suggest that recessions are not the appropriate time for fiscal consolidations which end up being selfdefeating. Furthermore, we evaluate the influence that financial markets could have on the real performance of the economy via the spread cost of sovereign bonds. In contrast to the claims provided by the supporters of expansionary austerity, fiscal rules depress the economic activity and worsen the state of public finance even when there is a feedback mechanism between the public debt to GDP ratio and the spread paid by the Government on its bonds.

On the monetary side, the switch to a "conservative" Taylor rule, which targets price stabilisation only, worsens the performance of the economy especially when fiscal rules are in place. Such costs are not compensated by significant benefits coming from inflation reduction, as the inflation rate is stable and low also when the Central Bank follows a dual-mandate monetary policy. The existence of bank-based and balance-sheet transmission channels of monetary policy seem to be responsible for the better performance of the dual-mandate Taylor rule (Bernanke et al., 1999; Boivin et al., 2010; Borio and Zhu, 2012). More precisely, this result is due to the interaction of the dual-mandate monetary policy with the Basel rule governing changes in credit supply. By reducing the pro-cyclicality of the macroprudential rule, the dual-mandate compensates the destabilising effect of the latter and provides both banks and firms with a stronger financial record at the eve of an economic crisis.

Finally, the effects of monetary and fiscal policies become sharper as the level of income inequality increases. As a consequence, fiscal-consolidation policies appear to be more painful when the income distribution is more skewed toward profits for they contribute to further reduce 
the aggregate demand.

The rest of the paper is organised as follows. In Section 2 we present the model, whose empirical validation is summarised in Section 3. The results of the policy experiments are reported in Section 4. Finally, Section 5 concludes.

\section{The model}

The economy is composed of a machine-producing sector made of $F_{1}$ firms (denoted by the subscript $i$ ), a consumption-good sector made of $F_{2}$ firms (denoted by the subscript $j$ ), $L^{S}$ consumers/workers, a banking sector made of $B$ commercial banks (denoted by the subscript $k$ ), a Central Bank and a public sector. Capital-good firms invest in R\&D and produce heterogeneous machines. Consumption-good firms combine machine tools bought from capital-good firms and labour in order to produce a final product for consumers. The banks provide credit to consumption-good firms using firms' savings. The Central Bank fixes the baseline interest rate in the economy and the macro prudential regulatory framework. Finally, the public sector levies taxes on firms' and banks' profits and pays unemployment benefits.

\subsection{The timeline of events}

In any given time period $(t)$, the following microeconomic decisions take place in sequential order:

1. Policy variables (e.g. capital requirement, tax rate, Central Bank interest rate, etc.) are fixed.

2. Total credit notionally providable by the banks to their clients is determined.

3. Machine-tool firms perform R\&D, trying to discover new products and more efficient production techniques and to imitate the technologies and the products of their competitors. They then signal their machines to consumption-good firms (under conditions of imperfect information).

4. Consumption-good firms decide how much to produce and invest. If internal funds are not enough, firms borrow from their bank. If gross investment is positive, consumption-good firms choose their supplier and send their orders.

5. In both industries firms hire workers according to their production plans and start producing. Consumption-good firms may get external finance from banks to pay for production (i.e., to advance wages).

6. The Government determines the amount of unemployment subsidies to allocate, possibly being limited by the fiscal rule.

7. Imperfectly competitive consumption-good market opens. The market shares of firms evolve according to their price competitiveness. 
8. Firms in both sectors compute their profits. If profits are positive, firms pay back their loans to their bank and deposit their net savings, if any.

9. Banks compute their profits and net worth. If the latter is negative they fail and they are bailed out by the Government.

10. Entry and exit take places. In both sectors firms with near zero market shares or negative net liquid assets are eschewed from the two industries and replaced by new ones.

11. Machines ordered at the beginning of the period are delivered and become part of the capital stock at time $t+1$.

At the end of each time step, aggregate variables (e.g. GDP, investment, employment...) are computed, summing over the corresponding microeconomic variables.

\subsection{The capital- and consumption-good industries}

Firms in the capital-good industry produce machine-tools using only labour. They innovate and imitate in order to increase the labour productivity of the machines they sell to the consumptiongood firms as well as to reduce their own production costs. ${ }^{4}$ Innovation and imitation are costly: firms need to invest a fraction of their past sales into the R\&D process. They sell their machinetools at a price which is defined with a fixed mark-up over their unit cost. Finally, as capital-good firms produce using the cash advanced by their customers, they do not need external funding from banks.

Consumption-good firms produce a homogeneous good using their stock of machines and labour under constant returns to scale. They plan their production on the grounds of adaptive expectations, and accordingly decide on their desired production level based on expected demand, together with desired and actual stock of inventories. If their capital stock is not sufficient to produce the desired amount, they invest in order to expand their production capacity, and may thus acquire machines of a more recent vintage than the one they already have. Their overall labour productivity thus evolves according to the technology embedded in their stock of capital.

Firms can also invest to replace the machines that have become obsolescent. Imperfect information affects the choice of the capital-good supplier: machine-tool firms "advertise" their machines' price and productivity levels by sending "brochures" to a subset of consumption-good firms, who in turn choose the machines with the lowest price and unit cost of production.

Once the desired levels of investment and production are decided, consumption-good firms have to finance their investments and production $\left(Q_{j, t}\right)$, as they advance worker wages and pay the ordered machines. Firms can use internal funds (cash flow) or external ones (loans) to do so. In line with a growing number of theoretical and empirical papers (e.g. Stiglitz and Weiss, 1981; Greenwald and Stiglitz, 1993; Hubbard, 1998) we assume imperfect capital markets. This implies that the financial structure of firms matters (external funds are more expensive than internal ones) and firms may be credit rationed. Indeed, banks are unable to allocate credit

\footnotetext{
${ }^{4}$ More information on the innovation and imitation processes can be found in the appendix, section A.1, which are detailed in Dosi et al. (2010) and Dosi et al. (2013).
} 
optimally due to imperfect access to information about the creditworthiness of the applicants, but rather use a "financial pecking-order" criterion (Myers, 1984). The imperfect substitutability of internal and external sources of finance implies that the Modigliani and Miller (1958) theorem does not hold: firms first use their internal source of funding $\left(N W_{j, t}\right)$ and if it is not enough they ask the remaining part to their bank. This financing hierarchy defines the demand for credit of each firm. A firm can be credit constrained so that it is not able to reach its desired production and/or investment levels. First, a loan-to-value ratio limits the maximum amount of debt each firm can sustain. Second, firms may not get the amount of external funding required to top up their available internal funds. ${ }^{5}$ Credit-constrained firms have to reduce their desired investment and production to the amount that they can finance. ${ }^{6}$ Finally, the interest rate paid on the loan $\left(r_{j, t}^{d e b}\right)$ depends on the Central Bank interest rate $\left(r_{t}\right)$ and on the firm's credit rating (see equation 5 below).

Consumption-good firms define their prices $\left(p_{j, t}\right)$ by applying a variable mark-up on their unit costs of production $\left(c_{j, t}\right)$, which in turn depend on the average labour productivity associated with their machine-tools. As shown in more detail in the appendix (see section A.2), the dynamics of the mark-ups is shaped by the variations of market shares. In turn, the latter evolve according to a "quasi replicator" dynamics: more competitive firms expand while firms with a relatively lower competitiveness level shrink (cf. equations 22 and 23 in the appendix).

Consumption-good firm profits are computed as the difference between firm revenues minus its expenses :

$$
\Pi_{j, t}=S_{j, t}+r^{D} N W_{j, t-1}-c_{j, t} Q_{j, t}-r_{j, t}^{d e b} D e b_{j, t},
$$

with total sales $S_{j, t}=p_{j, t} D_{j, t}$, production $\operatorname{costs} c_{j, t} Q_{j, t}$, and debt costs $r_{j, t}^{d e b} D e b_{j, t}$, where $D e b$ denotes the stock of debt. Firms pay taxes on their profits at the tax rate $t r$. Therefore, the investment choices of each firm and its net profits determine the evolution of its stock of liquid assets $\left(N W_{j, t}\right)$ :

$$
N W_{j, t}=N W_{j, t-1}+(1-t r) \Pi_{j, t}-c I_{j, t},
$$

where $c I_{j}$ is the amount of internal funds employed by firm $j$ to finance investment.

At the end of each period a firm exits if it has a (quasi) zero market share or if it goes bankrupt, i.e. the stock of its liquid assets becomes negative. We keep the number of firms fixed, hence any dead firm is replaced by a new one. ${ }^{7}$

\subsection{The banking sector}

As firms in the capital-good sector are paid before starting the production of machines, credit is provided only to consumption-good firms. In the banking sector there are $B$ commercial banks

\footnotetext{
${ }^{5}$ The credit allocation process defining the quantity and price obtained by the firm is detailed in section 2.3.

${ }^{6}$ In this case, firms give priority to production over investment.

${ }^{7}$ Furthermore, in line with the empirical literature on firm entry (Caves, 1998; Bartelsman et al., 2005), we assume that entrants are on average smaller than incumbents, with the stock of capital of new consumptiongood firms and the stock of liquid assets of entrants in both sectors being a fraction of the average stocks of the incumbents. The stock of capital of a new consumption-good firm is obtained multiplying the average stock of capital of the incumbents by a random draw from a Uniform distribution with support $\left[\phi_{1}, \phi_{2}\right], 0<\phi_{1},<\phi_{2} \leqslant 1$. In the same manner, the stock of liquid assets of an entrant is computed multiplying the average stock of liquid assets of the incumbents of the sector by a random variable distributed according to a Uniform with the same support. Finally, entrants embody a random copy of an incumbent's technology.
} 
that gather deposits and provide credit to firms. The number of banks is fixed and is related to the number of firms in the consumption-good sector $F_{2}$ :

$$
B=\frac{F_{2}}{a}
$$

where the positive integer $a$ can be taken as a proxy for the level of competition in the banking market. ${ }^{8}$ Bank-firm couples are drawn initially and maintained fixed over time (the relationship holds both for deposits and credit). Banks are heterogeneous in their number of clients. Following empirical evidence on the skewness of the bank size distribution (Berger et al., 1995; Ennis, 2001), banks' number of clients is determined by a random draw $N L_{k}$ from a Pareto distribution defined by the shape parameter pareto $a_{a}$. Therefore, each bank $k$ has a portfolio of clients $C l_{k}$ with clients listed as $c l=1, \ldots, C l_{k}$.

In what follows, we first present how total available credit is determined by each bank, and how credit is allocated to each firm. Next, we move to describe the organisation of the credit flow in the economy and the liquidity account of the banks. Finally, we report the management of banking failures.

\subsubsection{Supply and allocation of bank credit}

Banks are heterogeneous in terms of their fundamentals, their client portfolio, as well as their supply of credit, which is a function of their equity $\left(N W_{t}^{b}\right)$. On the one hand, capital adequacy requirements inspired by Basel-framework rules (see e.g. Delli Gatti et al., 2005; Ashraf et al., 2011; Raberto et al., 2012) constrain banks' credit supply. ${ }^{9}$ On the other hand, in line with the empirical evidence (BIS, 1999), banks maintain a buffer over the mandatory level of capital, whose magnitude is strategically altered over the business cycle according to their financial fragility (Bikker and Metzemakers, 2005; Becker and Ivashina, 2014). More precisely, following Adrian and Shin (2010) and Tasca and Battiston (2011), we proxy banks' fragility by the variable $L e v_{k, t}$, defined in our model as the accumulated bad debt to assets ratio. Therefore, given the parameter $\tau^{b} \in[0,1]$ fixed by the regulatory authority, the higher the bad-debt-to-asset ratio, the lower the credit the bank provides to its clients:

$$
T C_{k, t}=\frac{N W_{k, t-1}^{b}}{\tau^{b}\left(1+\beta \text { Lev }_{k, t-1}\right)},
$$

where $\beta>0$ is a parameter which measures banks' sensitivity to their financial fragility. Credit supply is thus impacted by changes in the banks' balance sheet, which itself is affected by bank profits net of loan losses. This creates a negative feedback loop from loan losses to changes in banks' equity with a reduction in the amount of credit supplied by the lender in the next period.

Each consumption-good firm needing credit applies to its bank for a loan. Banks take their allocation decisions by ranking the applicants in terms of their creditworthiness, defined by the ratio between past net worth $\left(N W_{j, t-1}\right)$ and past sales $\left(S_{j, t-1}\right)$. Banks provide credit as long as

\footnotetext{
${ }^{8}$ The empirical literature on topologies of credit markets (e.g. De Masi and Gallegati, 2007 for Italy, and De Masi et al., 2010 for Japan) defines this ratio as around 1 bank for 15 firms.

${ }^{9}$ Notice that this policy acts as an automatic de-stabiliser, due to its procyclical mechanism (Bikker and Metzemakers, 2005). More on that in section 4.1.
} 
their supply of credit $\left(T C_{k, t}\right)$ is not fully distributed. A firm's ability to obtain credit depends therefore on its financial status which determines its ranking, but also on the financial fragility of its bank. It follows that in any period the stock of loans of the bank satisfies the following constraint:

$$
\sum_{c l=1}^{C l_{k}} D e b_{c l, k, t}=\operatorname{Loan}_{k, t} \leqslant T C_{k, t} .
$$

\subsubsection{Interest rate structure}

Banks earn profits out of the loans they allocate as well as the government bonds they own (see below). In our setting, firm-bank links are fixed, thus interest rates on loans are not used by banks to compete between themselves, but rather to mirror the riskiness of their clients. The interest rate on loans $\left(r_{t}^{\text {deb }}\right)$ is computed with a mark-up on the Central Bank interest rate $\left(r_{t}\right)$. The latter is fixed by the Central Bank according to a Taylor rule (the seminal papers here are Howitt, 1992 and Taylor, 1993; see also Bernanke and Mishkin, 1997 for a review of current "inflation targeting" practices of Central Banks):

$$
r_{t}=r^{T}+\gamma_{\pi}\left(\pi_{t}-\pi^{T}\right)+\gamma_{U}\left(U^{T}-U_{t}\right), \quad \gamma_{\pi}>1, \gamma_{U} \geq 1
$$

where $\pi_{t}$ is the inflation rate of the period, $U_{t}$ the unemployment rate, $r^{T}, \pi^{T}, U^{T}$ are the target interest, inflation and unemployment rates respectively. In the benchmark parametrisation, the Central Bank pursues inflation stabilisation only $\left(\gamma_{U}=0\right)$. In the policy experiments (see Section 4 below), we will compare such a monetary policy rule with the one where the Central Bank follows a dual-mandate minimising also employment deviations $\left(\gamma_{U}>1\right)$. The dual-mandate Taylor rule employed in the model is well in tune with the recent monetary policy strategy pursued by the Federal Reserve (see Yellen, 2014). ${ }^{10}$

Banks fix the risk premium paid by their clients depending on their position in the credit ranking. In every period, four credit classes are created by the banks, corresponding to the quartiles in their ranking of clients. Given the base loan rate $r_{t}^{d e b}=\left(1+\mu^{d e b}\right) r_{t}$, firm $j$ in credit class $q=1,2,3,4$ pays the interest rates :

$$
r_{j, t}^{d e b}=r_{t}^{d e b}\left(1+(q-1) k_{\text {const }}\right)
$$

with $\mu^{d e b}>0$ and $k_{\text {const }}$ a scaling parameter. ${ }^{11}$

Firms' deposits are rewarded at the rate $r_{t}^{D}$, banks' reserves at the Central Bank yield the reserves rate $r_{t}^{r e s}$, and government bonds pay an interest rate $r_{t}^{\text {bonds }}=\left(1+\mu^{\text {bonds }}\right) r_{t}$, with $-1<\mu^{b o n d s}<0$. The different interest rates are set so that $r_{t}^{D} \leq r_{t}^{r e s} \leq r_{t}^{b o n d s} \leq r \leq r_{t}^{\text {deb }}$.

\footnotetext{
${ }^{10}$ Instead of using the canonical output gap in the Taylor rule, we choose the unemployment gap also because the estimation of the potential output is not straightforward in a model characterised by endogenous technical change. In line with the empirical evidence (see e.g. Walsh, 2009), we set $\gamma_{U}>1$ when the dual-mandate monetary policy is in place.

${ }^{11}$ The simulation results shown below cf. (Section 4) are robust to the inclusion of counter-cyclical spreads in equation 5 in line with the empirical evidence (Olivero, 2010).
} 


\subsubsection{Bank net worth, failure and bailout policies}

The profits of bank $k\left(\Pi_{k, t}^{b}\right)$ can be computed as follows:

$$
\Pi_{k, t}^{b}=\sum_{c l=1}^{C l_{k}} r_{c l, t}^{d e b} D e b_{c l, t}+r^{r e s} C_{a s h}{ }_{k, t}+r_{t}^{b o n d s} \text { Bonds }_{k, t}-r^{D} \operatorname{Dep}_{k, t}-\text { BadDebt }_{k, t}
$$

where $D e b_{c l, t}$ represents the debt of client $c l, \operatorname{Cash}_{k, t}$ are the liquidities, Bonds $s_{k, t}$ is the stock of government bonds, and BadDebt $k, t$ captures non-performing loans. Banks experience loan losses whenever one of their clients goes bankrupt and exits the market with a positive debt. Banks' profits net of taxes $\left(N e t \Pi_{k, t}^{b}=(1-t r) * \Pi_{k, t}^{b}\right)$ are then added to their net worth $\left(N W_{k, t}^{b}\right)$, which is equal to the difference between assets and liabilities. Banks' assets are composed of their liquidity stock $\left(\operatorname{Cash}_{k, t}\right)$, their stock of government bonds $\left(\right.$ Bonds $\left._{k, t}\right)$ and their stock of loans $\left(\right.$ Loans $\left._{k, t}\right)$, while firms' deposits $\left(\right.$ Depo $\left._{k, t}\right)$ are the only liabilities. Accordingly the net worth of the bank reads :

$$
N W_{k, t}^{b}=\text { Loans }_{k, t}+\operatorname{Cash}_{k, t}+\text { Bonds }_{k, t}-\operatorname{Depo}_{k, t}+N e t \Pi_{k, t}^{b}
$$

Loan losses represent a negative shock to bank profits, which may well become negative. If the net worth of the bank is not sufficient to cover such losses, the bank goes bankrupt. Whenever, a bank fails $\left(N W_{k, t}^{b}<0\right)$, the Government steps in and bails it out providing fresh capital. The cost of the public bail out $\left(\right.$ Gbailout $\left._{t, k}\right)$ is the difference between the failed bank's equity before and after the public intervention. We assume that the bank's equity after the bailout is a fraction of the smallest incumbent's equity, provided it respects the capital adequacy ratio. Mirroring the entry rule in the real sector (see Footnote 7 ), this fraction is a random draw from a Uniform distribution with support $\left[\phi_{1}, \phi_{2}\right], 0<\phi_{1},<\phi_{2} \leqslant 1$.

\subsection{Consumption and the Government sector}

The consumption of workers is obviously linked to their wage. We assume that the wage rate $\left(w_{t}\right)$ is determined by institutional and market factors, with both indexation mechanisms upon the inflation gap, average productivity, and the unemployment rate:

$$
\frac{\Delta w_{t}}{w_{t-1}}=\pi^{T}+\psi_{1}\left(\pi_{t-1}-\pi^{T}\right)+\psi_{2} \frac{\Delta \overline{A B}_{t}}{\overline{A B}_{t-1}}-\psi_{3} \frac{\Delta U_{t}}{U_{t-1}}
$$

where $\overline{A B_{t}}$ is the average labour productivity at time $t$ and $\psi_{1,2,3}>0$. The labour market does not feature any Walrasian clearing mechanism. Accordingly, involuntary unemployment and labour rationing may naturally emerge.

Unemployed workers - computed as the difference between the fixed labour supply $\left(L^{S}\right)$ and firms' total labour demand $\left(L_{t}^{D}\right)$ - receive a public subsidy $\left(w_{t}^{u}\right)$ which is a fraction of the current wage, i.e. $w_{t}^{u}=\varphi w_{t}$, with $\varphi \in[0,1]$. The total amount of unemployment subsidies to be paid by the Government $\left(G_{t}\right)$ is therefore:

$$
G_{t}=w_{t}^{u}\left(L^{S}-L_{t}^{D}\right)
$$


Aggregate consumption $\left(C_{t}\right)$ depends on the income of both employed and unemployed workers

$$
C_{t}=w_{t} L_{t}^{D}+G_{t}
$$

Taxes paid by firms and banks on their profits are gathered by the Government at the fixed tax rate $t r$. Public expenditures are composed of the cost of the debt $\left(D e b t_{t}^{\text {cost }}\right)$, the bank bailout cost $\left(\right.$ Gbailout $_{t}=\sum_{k=1}^{B}$ Gbailout $\left._{k, t}\right)$ and the unemployment subsidies $\left(G_{t}\right)$. Public deficit is then equal to:

$$
D e f_{t}=\text { Debtt }_{t}^{\text {cost }}+\text { Gbailout }_{t}+G_{t}-\text { Tax }_{t} .
$$

If $D e f_{t}>0$, the Government has to issue new bonds, which are bought by banks according to their share in the total supply of credit. ${ }^{12}$ If the demand for bonds from the Government is higher than what banks are able to buy, the Central Bank steps in and buys the remaining debt. If $D e f_{t}<0$, the Government uses the surplus to repay its debt.

The debt-related expenditures at time $t$ are therefore:

$$
\operatorname{Debt}_{t}^{\text {cost }}=r_{t}^{\text {bonds }} \text { Bonds } s_{t-1}^{\text {stock }}
$$

The dynamics generated at the micro-level by decisions of a multiplicity of heterogeneous, adaptive agents and by their interaction mechanisms is the explicit microfoundation of the dynamics for all aggregate variables of interest (e.g. output, investment, employment, etc.). The model satisfies the standard national account identities: the sum of value added of capital- and consumption goods firms $\left(G D P_{t}\right)$ equals their aggregate production (in our simplified economy there are no intermediate goods). That in turn coincides with the sum of aggregate consumption, investment and change in inventories $\left(\Delta N_{t}\right)$ :

$$
\sum_{i=1}^{F_{1}} Q_{i, t}+\sum_{j=1}^{F_{2}} Q_{j, t}=Y_{t} \equiv C_{t}+I_{t}+\Delta N_{t}
$$

\subsection{Fiscal and monetary policy rules}

In the benchmark scenario, the tax and unemployment subsidy rates are kept fixed throughout all the simulations. This implies that they act as automatic stabilisers and that the public deficit is free to fluctuate over time. ${ }^{13}$ Furthermore, in the policy experiments below (cf. Section 4) we study the effect of different fiscal rules, namely the 3\%-deficit rule (mirroring the conditions in the European Stability and Growth Pact, $S G P$ and $\left.S G P_{e c}\right)$ and the debt-reduction rule (mirroring the Fiscal Compact, $F C$ and $F C_{e c}$ ). With regards to monetary policy, besides the benchmark Taylor rule adjusting only to the inflation gap $\left(T R_{\pi}, \gamma_{\pi}>1, \gamma_{U}=0\right)$, we implement a dual-mandate Taylor rule $\left(T R_{\pi, U}, \gamma_{\pi}>1, \gamma_{U}>1\right)$. Finally, we detail below the "lender of

\footnotetext{
${ }^{12}$ Banks buy government bonds employing only their net profits. Simulation results do not change if government debt is allocated to banks according to their profit shares instead of credit shares.

${ }^{13}$ McKay and Reis (2013) find that automatic stabilisers can strongly contribute to dampen business cycle volatility, especially through the redistribution and social-insurance channels. See also Solow (2005) and Blanchard et al. (2010) on the case for stronger automatic stabilisers as a tool for better macroeconomic policy.
} 
last resort" ( $L L R_{\pi}$ and $\left.L L R_{\pi, U}\right)$ and "bonds spread adjustment" (spread) policies, which are concerned with the setting of the interest rate on sovereign bonds.

3\%-deficit rule. With a fiscal rule mimicking the SGP, the Government is constrained in the size of its public deficit:

$$
D e f_{t} \leq \operatorname{de} f_{\text {rule }} G D P_{t-1}
$$

with $d e f_{\text {rule }}=0.03$ being the maximum value of the deficit to GDP ratio allowed. When the rule is binding, the Government has to reduce the amount of subsidies distributed in the period $\left(G_{t}\right) .{ }^{14}$ In our experiments, we implement two versions of such a rule: the first one corresponds to the original version of the Stability and Growth Path $(S G P)$, while the second one includes its 2005 revision allowing for more flexibility in bad times (Council of the European Union, 2005). More precisely, the fiscal rule is not binding if the output growth rate is negative. We will refer to this second case as the SGP supplemented with an "escape clause" $\left(S G P_{e c}\right)$.

Debt-reduction rule. The second fiscal rule is inspired by the Fiscal Compact. In this case we add to the deficit over GDP ratio limit a debt-reduction rule: if the ratio of public debt on GDP is over the SGP target of $60 \%$, it should be reduced by $1 / 20$ th $(5 \%)$ of the difference between the current and target levels in every year. ${ }^{15}$ If the debt-reduction rule is binding, the surplus necessary to satisfy it is:

$$
D e f_{t}=-0.05\left(\frac{D e b t_{t-1}}{G D P_{t-1}}-0.60\right)
$$

In this case, both the excessive debt (60\% of GDP) and excessive deficit ( $3 \%$ of GDP) conditions have to be met, which means that the maximum deficit allowed is the minimum between the one of the $3 \%$ rule and the one of the debt reduction rule. As the the debt-reduction condition requires a surplus, it will always prevail over the deficit one. Also in this case, if the rule is binding, the amount of unemployment subsidies is reduced accordingly. In the experiments that follows we will consider a Fiscal Compact rule both with $\left(F C_{e c}\right)$ and without $(F C)$ an "escape clause".

Lender of last resort. In order to limit the cost of public debt, the Central Bank intervenes in the sovereign bonds market so that the interest rate is always equal to $\bar{r}_{\text {bonds }}=0.01$. This policy may be associated with a single mandate Taylor rule $\left(L L R_{\pi}\right)$ or a dual-mandate Taylor rule $\left(L L R_{\pi, U}\right)$.

Bonds spread adjustment policy. So far we have not considered any feedback mechanism going from the level of public debt to its financing costs. Several models assume a positive correlation between public debt to GDP levels and bond yields, yet the empirical debate on such a link is still not resolved (Alper and Forni, 2011). However, as a positive correlation is

\footnotetext{
${ }^{14}$ If the deficit rule is binding, the Government sets as priority the bailout of banks before the payment of unemployment subsidies, which have to be reduced to satisfy the $3 \%$ deficit condition.

${ }^{15}$ It is not the exact replica of the Fiscal Compact as we do not consider the limit to the structural deficit. Still, we are close in spirit to the FC as we jointly consider the debt reduction and the $3 \%$-deficit rules, and we also consider the escape clause in case of recession.
} 

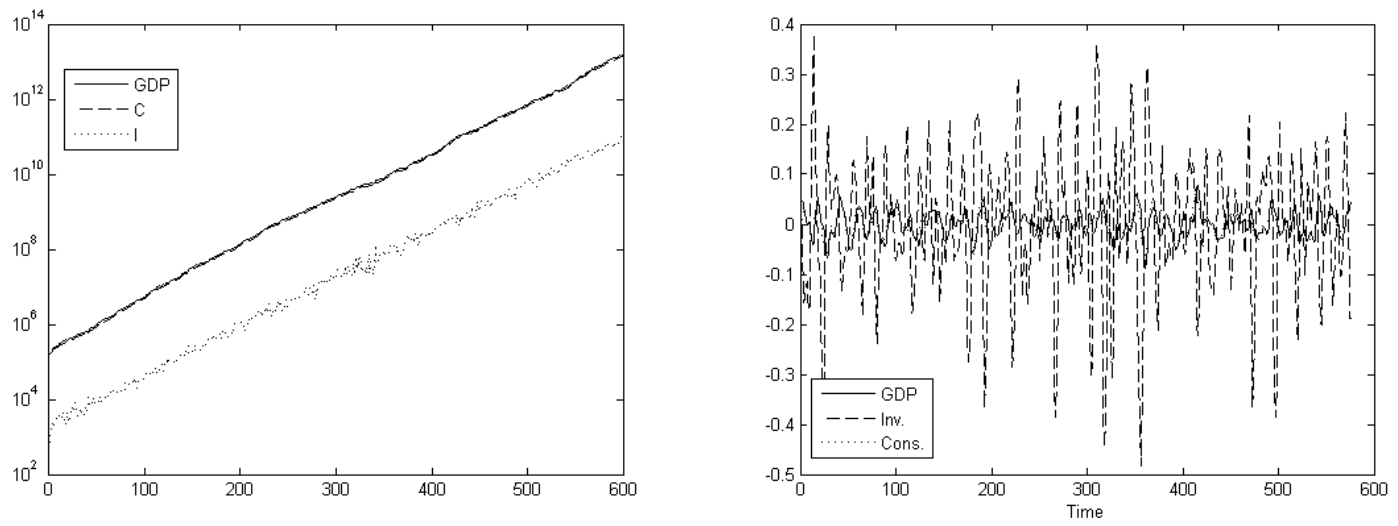

Figure 1: Output, investment and consumption time series; left: logs; right: bandpass-filtered $(6,32,12)$ series.

apparent in some extreme cases, ${ }^{16}$ we perform a battery of simulation exercises where a debt risk premium is added to the interest rate on sovereign bonds. This introduces a positive feedback effect on the sovereign bond interest rate stemming from excessive public debt:

$$
r_{t}^{b o n d s}=\left(1+\mu^{b o n d s}\right) r_{t}\left(1+\rho \frac{D e b t_{t-1}}{G D P_{t-1}}\right)
$$

In tune with the empirical evidence (Alper and Forni, 2011), we set the $\rho$ parameter to 0.04 .

\section{Empirical validation}

The analysis of the properties of the model is performed via computer simulations. In what follows, we perform extensive Montecarlo simulations to wash away across-simulation variability. Consequently, all results below refer to across-run averages over several replications. ${ }^{17}$ The benchmark parametrisation is presented in Table 7 in the Appendix. Before addressing policy questions, we first study whether in the "benchmark" setup the model is "empirically validated", i.e. it is able to reproduce a wide spectrum of macroeconomic and microeconomic stylised facts, possibly a higher number than those replicated in Dosi et al. (2006, 2008, 2010, 2013).

Let us start by considering how the model fares as to macroeconomic empirical regularities: much more details on these results in Dosi et al. (2010, 2013). We find that the model is able to robustly generate endogenous self-sustained growth patterns characterised by the presence of persistent fluctuations (cf. Figure 1, left). Moreover, bandpass-filtered output, investment and consumption series (Bpf, cf. Baxter and King, 1999) display business cycle dynamics (see Figure 1, right) similar to those observed in real data (e.g. Stock and Watson, 1999; Napoletano

\footnotetext{
${ }^{16}$ De Grauwe and Ji (2013) test the correlation between spreads and debt-to-GDP ratios in eurozone countries for the period 2000-2011. A positive link emerges only in the cases of Greece, Ireland and Portugal after 2008.

${ }^{17}$ All the simulation results refers to 100 Montecarlo independent runs, each of them involving 600 time steps. Extensive tests show that the results are robust to changes in the initial conditions for the microeconomic variables of the model. In addition, they show that, for the statistics under study, Montecarlo distributions are sufficiently symmetric and unimodal. This justifies the use of across-run averages as meaningful synthetic indicators. All our results do not significantly change if the Montecarlo sample size is increased.
} 


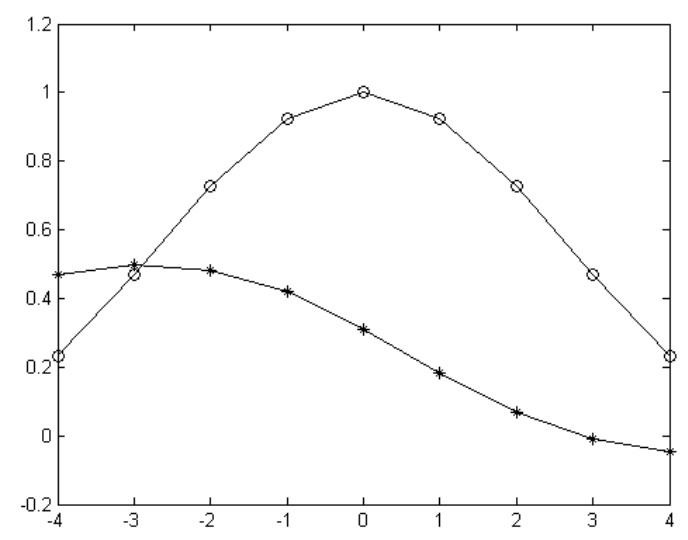

Figure 2: Average cross-correlations of bad debt with private debt at different leads and lags (diamonds) together with average debt autocorrelation (circles).

et al., 2006): investment is more volatile than GDP while consumption is less. Considering the co-movements between macroeconomic variables at the business cycle frequencies, we find that, in line with the empirical evidence, consumption is procyclical and coincident, net investment, changes in inventories, productivity, nominal wages and inflation are procyclical; unemployment, prices and mark-ups are countercyclical (for the empirics and discussion cf. Stock and Watson, 1999; Rotemberg and Woodford, 1999). ${ }^{18}$ Finally, the output growth-rate distribution generated by the model exhibits fat tails well in tune with the empirical evidence (Fagiolo et al., 2008).Note that DSGE models are not able to match such empirical regularity even if they are fed with fat-tailed shocks (Ascari et al., 2013).

The model also matches the major business cycle stylized facts concerning credit (as reported for instance by Bikker and Metzemakers, 2005). Indeed, firms' total debt and bank profits are pro-cyclical, while loan losses are counter-cyclical. Studies about credit dynamics (e.g. Mendoza and Terrones, 2012) have found that credit booms are often followed by banking or currency crises characterising a boom-bust cycle. These aggregate dynamics are in tune with the "Minskyan" evolution of firms' financial health over the cycle. At the onset of an expansionary phase firm profit and cash flow improve. At the same time production and investment expenditures soar, thus inducing a rise in firm debt. In turn, the rise in debt costs gradually erodes firms' cash flows and savings, paving the way to higher bankruptcy ratios and setting the stage for the incoming recession phase. In line with such a dynamics we find that higher levels of firm debt lead to higher firm default: bad debt is positively correlated with firm debt, with a lag (cf. fig. 2). Loan growth thus entails higher default rates, further weakening banks' balance sheet (in line with the evidence in Foos et al., 2010).

The economic and banking crises generated by the model match the empirical distributional properties of recessions and fiscal costs of banking failures. In line with Ausloos et al. (2004), the large majority of economic crises are short-lived, lasting only one period. Moreover, the distribution of recession durations is exponential (Wright, 2005) and the distribution of banking

\footnotetext{
${ }^{18}$ Due to space constraints, we do not report all the results related to the empirical validation of the model. The results are available from the authors upon request.
} 


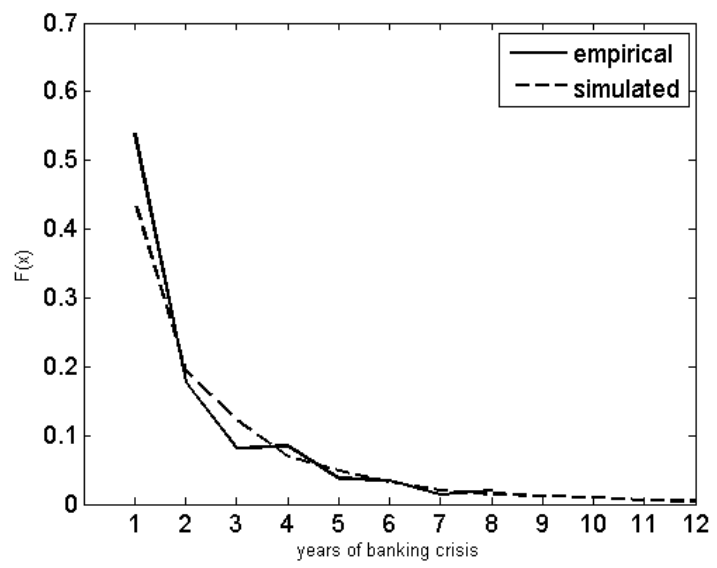

Figure 3: Distribution of banking crisis duration; simulated vs. empirical data. The length of a banking crisis is defined as the number of consecutive years with at least one banking failure in the country (Reinhart and Rogoff, 2009).

crisis duration closely tracks the empirical one (see Figure 3). Finally, in the benchmark model, recessions can last up to 8 years, close to the maximum of 7 years observed empirically. Moving to stylized facts about banking crises (Laeven and Valencia, 2008; Reinhart and Rogoff, 2009), we find, again in tune with the empirical literature, that the distribution of the ratio between fiscal costs of banking crises and GDP is characterised by excess kurtosis, with tails much heavier than those resulting from any normal distribution.

Finally, the model is also able to replicate a large array of microeconomic empirical regularities (see e.g. Bartelsman and Doms, 2000; Dosi, 2007 ). More specifically, firm size distributions are right skewed; firm growth-rate distributions are fat tailed; firms are heterogeneous in terms of productivities and such differences are persistent over time; firms invest in a lumpy fashion. Note that this is one of the major advances of agent-based models vis-à-vis DSGE ones, which by building on the representative agent cannot account for any meaningful heterogeneity at the microeconomic level. ${ }^{19}$

\section{Policy experiments}

The results described in the previous section, showing the ability of the model to robustly account for a wide set of empirical regularities, lend robustness to the policy experiments which we perform on its grounds. Here we primarily focus on the impact of different combinations of fiscal and monetary policies on a set of target variables. ${ }^{20}$ These include the long-term GDP growth rates and the long-term public debt to GDP ratios. Other variables, such as GDP volatility, the unemployment rate and the occurrence of economic crises (defined as the number of periods in which the fall in GDP is higher than 3\%) allow to evaluate the effect of policies at

\footnotetext{
${ }^{19}$ See Kirman (1992) for a critique of the representative agent assumption which ought to be considered the definitive statement on such notion.

${ }^{20} \mathrm{On}$ the possible interactions between fiscal and monetary policies in otherwise standard models see Leith and Wren-Lewis (2000); Woodford (2011); Ascari and Rankin (2013).
} 


\begin{tabular}{lccccc}
\hline \hline & $T R_{\pi}$ & $T R_{\pi, U}$ & $L L R_{\pi}$ & $L L R_{\pi, U}$ & spread \\
\hline norule & 1 & $1.019^{* *}$ & $1.001^{*}$ & $1.016^{* *}$ & $0.994^{* *}$ \\
& & $(37.326)$ & $(2.028)$ & $(32.689)$ & $(10.169)$ \\
\multirow{5}{S}{ SP } & $0.527^{* *}$ & $1.014^{* *}$ & $0.716^{* *}$ & $0.970^{* *}$ & $0.794^{* *}$ \\
& $(68.935)$ & $(11.487)$ & $(51.914)$ & $(11.002)$ & $(39.823)$ \\
$F C$ & $0.572^{* *}$ & $0.958^{* *}$ & $0.676^{* *}$ & $0.954^{* *}$ & $0.765^{* *}$ \\
& $(64.993)$ & $(12.958)$ & $(53.769)$ & $(14.183)$ & $(48.628)$ \\
$S G P_{e c}$ & $0.995^{* *}$ & $1.013^{* *}$ & $0.996^{* *}$ & $1.017^{* *}$ & $0.991^{* *}$ \\
& $(5.509)$ & $(25.733)$ & $(6.918)$ & $(33.244)$ & $(16.653)$ \\
$F C_{e c}$ & $0.992^{* *}$ & $1.021^{* *}$ & $0.995^{* *}$ & $1.017^{* *}$ & $0.997^{* *}$ \\
& $(13.881)$ & $(41.713)$ & $(7.763)$ & $(34.634)$ & $(5.242)$ \\
\hline \hline
\end{tabular}

Table 1: Fiscal and monetary policy interactions. Normalised values of average GDP growth rates across experiments. Absolute value of simulation t-statistic of $H_{0}$ : "no difference between baseline and the experiment" in parentheses; $\left({ }^{* *}\right)$ significant at $1 \%$ level, $\left({ }^{*}\right)$ significant at $5 \%$ level. Fiscal policies: no fiscal rule (norule); $3 \%$ deficit rule $(S G P)$; debt-reduction rule $(F C)$; $S G P$ with escape clause $\left(S G P_{e c}\right) ; F C$ with escape clause $\left(F C_{e c}\right)$. Monetary policies: Taylor rule indexed on inflation only $\left(T R_{\pi}\right)$; dual-mandate Taylor rule $\left(T R_{\pi, U}\right)$; "lender of last resort" $\left(L L R_{\pi}\right) ; L L R$ with dual-mandate $\left(L L R_{\pi, U}\right)$; bonds spread adjustment policy (spread).

business cycle frequencies. Finally, we include indicators related to the stability of the banking sector (the bank failure rates) as well as its impact on the real sector (financial constraints to firms).

The analysis proceeds in two steps. First, we explore the possible interactions between fiscal and monetary policies for a given level of income distribution. Second, we generalise the previous analysis by conditioning the impact of different policy combinations to different income inequality scenarios.

\subsection{Fiscal and monetary policy interactions}

In the baseline scenario, fiscal policy is not constrained (norule): automatic stabilisers can fully dampen business cycles fluctuations without being limited by government deficit. At the same time, the Central Bank pursues price stabilisation only by following a Taylor rule indexed just upon inflation $\left(T R_{\pi}\right)$. How do alternative combinations of fiscal and monetary policies affect the dynamics of the economy? The results of such analysis are reported in Tables 1-6. Each entry in the tables is the ratio between the Montecarlo average of the macroeconomic variable (e.g. output growth rate, the unemployment rate, etc) under a given fiscal and monetary policy mix and the one generated by the scenario with the baseline fiscal and monetary policies (norule, $\left.T R_{\pi}\right)$.

Fiscal rules. Let us start by examining the impact of different fiscal policies ${ }^{21}$ (as from Section $2.5)$ under the baseline monetary policy $\left(T R_{\pi}\right)$. The $S G P$ and $F C$ fiscal rules have a strong

\footnotetext{
${ }^{21}$ Our agent-based model allows us to study the effects of fiscal-consolidation policies in a framework where policy activations are well defined endogenous events and so are the ensuing outcomes (on e.g. the sovereign debt to GDP ratio). This is in line with empirical observations suggesting that the effects of fiscal policies change according to the state of the economy (see e.g. Auerbach and Gorodnichenko, 2012) or of credit markets (Ferraresi et al., 2013).
} 


\begin{tabular}{cccccc}
\hline \hline & $T R_{\pi}$ & $T R_{\pi, U}$ & $L L R_{\pi}$ & $L L R_{\pi, U}$ & spread \\
\hline norule & 1 & $0.865^{* *}$ & $1.015^{* *}$ & $0.874^{* *}$ & $1.011^{* *}$ \\
& & $(60.202)$ & $(5.428)$ & $(57.889)$ & $(3.842)$ \\
$S G P$ & $14.645^{* *}$ & $2.760^{* *}$ & $11.365^{* *}$ & $2.950^{* *}$ & $12.873^{* *}$ \\
& $(74.659)$ & $(24.015)$ & $(66.776)$ & $(43.700)$ & $(81.029)$ \\
$F C$ & $16.204^{* *}$ & $3.172^{* *}$ & $12.085^{* *}$ & $3.201^{* *}$ & $14.009^{* *}$ \\
& $(78.478)$ & $(41.733)$ & $(64.514)$ & $(47.155)$ & $(90.877)$ \\
$S G P_{e c}$ & $1.408^{* *}$ & $1.027^{* *}$ & $1.341^{* *}$ & 0.999 & $1.487^{* *}$ \\
& $(58.560)$ & $(4.501)$ & $(52.802)$ & $(0.292)$ & $(80.512)$ \\
$F C_{e c}$ & $1.624^{* *}$ & $0.980^{* *}$ & $1.543^{* *}$ & 0.997 & $1.530^{* *}$ \\
& $(71.660)$ & $(6.338)$ & $(64.215)$ & $(0.655)$ & $(69.624)$ \\
\hline \hline
\end{tabular}

Table 2: Fiscal and monetary policy interactions. Normalised values of average GDP volatility across experiments. Absolute value of simulation t-statistic of $H_{0}$ : "no difference between baseline and the experiment" in parentheses; $\left({ }^{* *}\right)$ significant at $1 \%$ level, $\left({ }^{*}\right)$ significant at $5 \%$ level.

\begin{tabular}{cccccc}
\hline \hline & $T R_{\pi}$ & $T R_{\pi, U}$ & $L L R_{\pi}$ & $L L R_{\pi, U}$ & spread \\
\hline norule & 1 & $0.322^{* *}$ & $1.217^{* *}$ & $0.290^{* *}$ & $1.068^{* *}$ \\
& & $(59.033)$ & $(13.879)$ & $(64.093)$ & $(4.681)$ \\
$S G P$ & $5.692^{* *}$ & $0.909^{* *}$ & $4.844^{* *}$ & $1.312^{* *}$ & $4.201^{* *}$ \\
& $(80.950)$ & $(5.549)$ & $(75.711)$ & $(10.270)$ & $(68.422)$ \\
$F C$ & $5.706^{* *}$ & $1.383^{* *}$ & $4.430^{* *}$ & $1.395^{* *}$ & $4.963^{* *}$ \\
& $(75.846)$ & $(13.505)$ & $(63.259)$ & $(12.561)$ & $(74.429)$ \\
$S G P_{e c}$ & $1.419^{* *}$ & $0.343^{* *}$ & $1.563^{* *}$ & $0.334^{* *}$ & $1.680^{* *}$ \\
& $(20.881)$ & $(55.275)$ & $(25.356)$ & $(57.573)$ & $(34.949)$ \\
$F C_{e c}$ & $1.948^{* *}$ & $0.317^{* *}$ & $1.746^{* *}$ & $0.331^{* *}$ & $1.679^{* *}$ \\
& $(39.284)$ & $(58.856)$ & $(32.536)$ & $(57.257)$ & $(31.392)$ \\
\hline \hline
\end{tabular}

Table 3: Fiscal and monetary policy interactions. Normalised values of average unemployment rate across experiments. Absolute value of simulation t-statistic of $H_{0}$ : "no difference between baseline and the experiment" in parentheses; $\left({ }^{* *}\right)$ significant at $1 \%$ level, $\left({ }^{*}\right)$ significant at $5 \%$ level.

and negative impact on short-run performance of the economy by increasing unemployment, output volatility and the likelihood of economic crises (cf. the second column of Tables 24). Such depressing effects spill into the long-run, considerably reducing GDP growth (see Table 1). The deterioration of the macroeconomic conditions lead to an explosion of the ratio between public debt and GDP (see Table 6). As a consequence, austerity policies appear to be self-defeating, in line with the empirical evidence (Guajardo et al., 2011; Blanchard and Leigh, 2013). ${ }^{22}$ The dismal performance of fiscal rules is due to the fact that they constrain government deficit especially during recessions when the smoothing effects of automatic stabilisers are mostly needed (McKay and Reis, 2013). This further depresses aggregate demand and exacerbates the fall of output, ultimately increasing the ratio between sovereign debt and GDP.

The apparent negative correlation between GDP growth and public debt emerges in our

\footnotetext{
${ }^{22}$ Although not modeled here, De Grauwe and Ji (2013) also stress that investors' distrust movements in the bonds markets can further accentuate the negative impact of austerity rules in the case of monetary unions such as the eurozone.
} 


\begin{tabular}{cccccc}
\hline \hline & $T R_{\pi}$ & $T R_{\pi, U}$ & $L L R_{\pi}$ & $L L R_{\pi, U}$ & spread \\
\hline norule & 1 & $0.587^{* *}$ & $1.032^{* *}$ & $0.613^{* *}$ & $1.031^{* *}$ \\
& & $(225.287)$ & $(14.873)$ & $(218.896)$ & $(14.603)$ \\
$S G P$ & $1.983^{* *}$ & $0.813^{* *}$ & $1.803^{* *}$ & $0.882^{* *}$ & $1.647^{* *}$ \\
& $(417.028)$ & $(102.498)$ & $(355.643)$ & $(57.326)$ & $(408.125)$ \\
$F C$ & $1.880^{* *}$ & $0.934^{* *}$ & $1.623^{* *}$ & $0.931^{* *}$ & $1.798^{* *}$ \\
& $(361.540)$ & $(32.051)$ & $(277.603)$ & $(32.499)$ & $(504.052)$ \\
$S G P_{e c}$ & $1.505^{* *}$ & $0.672^{* *}$ & $1.472^{* *}$ & $0.699^{* *}$ & $1.777^{* *}$ \\
& $(225.563)$ & $(179.190)$ & $(222.064)$ & $(162.997)$ & $(356.379)$ \\
$F C_{e c}$ & $1.953^{* *}$ & $0.675^{* *}$ & $1.683^{* *}$ & $0.691^{* *}$ & $1.836^{* *}$ \\
& $(452.426)$ & $(179.393)$ & $(319.376)$ & $(168.617)$ & $(373.843)$ \\
\hline \hline
\end{tabular}

Table 4: Fiscal and monetary policy interactions. Normalised values of average likelihood of economic crisis across experiments. Absolute value of simulation t-statistic of $H_{0}$ : "no difference between baseline and the experiment" in parentheses; $\left(^{* *}\right)$ significant at $1 \%$ level, $\left({ }^{*}\right)$ significant at $5 \%$ level.

\begin{tabular}{lccccc}
\hline \hline & $T R_{\pi}$ & $T R_{\pi, U}$ & $L L R_{\pi}$ & $L L R_{\pi, U}$ & spread \\
\hline norule & 1,000 & $1,140^{* *}$ & $0,964^{* *}$ & $1,145^{* *}$ & $0,984^{* *}$ \\
& & $(62,056)$ & $(11,762)$ & $(65,162)$ & $(5,311)$ \\
SGP & $0,956^{* *}$ & $1,128^{* *}$ & $0,935^{* *}$ & $1,117^{* *}$ & $0,951^{* *}$ \\
& $(14,816)$ & $(56,759)$ & $(21,356)$ & $(49,783)$ & $(16,623)$ \\
$F C$ & $0,975^{* *}$ & $1,103^{* *}$ & $0,992^{* *}$ & $1,113^{* *}$ & $0,932^{* *}$ \\
& $(8,510$ & $(42,740)$ & $(2,830)$ & $(47,242)$ & $(22,733)$ \\
$S G P_{e c}$ & $0,992^{*}$ & $1,142^{* *}$ & 0,999 & $1,139^{* *}$ & $0,939^{* *}$ \\
& $(2,493)$ & $(48,671)$ & $(0,244)$ & $(61,739)$ & $(19,614)$ \\
$F C_{e c}$ & $0,962^{* *}$ & $1,142^{* *}$ & $0,981^{* *}$ & $1,141^{* *}$ & $0,023^{* *}$ \\
& $(12,054)$ & $(62,848)$ & $(6,387)$ & $(62,509)$ & $(9,056)$ \\
\hline \hline
\end{tabular}

Table 5: Fiscal and monetary policy interactions. Normalised values of average inflation rate across experiments. Absolute value of the simulation t-statistic of $H_{0}$ : "no difference between baseline and the experiment" in parentheses; $\left({ }^{* *}\right)$ significant at $1 \%$ level, $\left({ }^{*}\right)$ significant at $5 \%$ level.

model as well as in some empirical studies (e.g. Presbitero, 2006; Lof and Malinen, 2013). The crucial point concerns the direction of causality linking GDP growth to public debt. If the latter ultimately led to lower GDP growth, austerity policies should be expansionary, as advocated by Giavazzi and Pagano (1996) and Alesina and Ardagna (2010). Conversely, if lower growth led to higher debt, austerity policies would turn out to be self-defeating. Our results support the second view, in line with the empirical evidence by a growing number of scholars, from Poterba (1995) all the way to Guajardo et al. (2011).

Fiscal rules with escape clauses. Many escape clauses suspending the implementation of fiscal rules in case of "exceptional circumstances" have been introduced in recent years (Schaechter et al., 2012). Nevertheless the debate about the importance of taking into account such extraordinary events is still open. Let us study what happens if we add escape clauses in case of recessions to the fiscal rules of the European Stability and Growth Pact and the Fiscal compact.

Simulation results show that the introduction of escape clauses $\left(S G P_{e c}\right.$ and $\left.F C_{e c}\right)$ consid- 


\begin{tabular}{lccccc}
\hline \hline & $T R_{\pi}$ & $T R_{\pi, U}$ & $L L R_{\pi}$ & $L L R_{\pi, U}$ & spread \\
\hline norule & 1,000 & $-50,648^{* *}$ & $1,294^{* *}$ & $-53,064^{* *}$ & $1,361^{* *}$ \\
& & $(303,770)$ & $(3,627)$ & $(320,025)$ & $(4,265)$ \\
$S G P$ & $+\infty$ & $-45,545^{* *}$ & $+\infty$ & $+\infty$ & $+\infty$ \\
& & $(90,107)$ & & & \\
$F C$ & $+\infty$ & $-30,529^{* *}$ & $+\infty$ & $31,939^{* *}$ & $+\infty$ \\
& & $(32,790)$ & & $(6,419)$ & \\
$S G P_{\text {ec }}$ & $1,763^{* *}$ & $-53,955^{* *}$ & $1,500^{* *}$ & $-51,714^{* *}$ & $2,958^{* *}$ \\
& $(7,744)$ & $(289,835)$ & $(5,184)$ & $(288,370)$ & $(19,334)$ \\
$F C_{e c}$ & $4,078^{* *}$ & $-51,369^{* *}$ & $2,205^{* *}$ & $-52,081^{* *}$ & $2,590^{* *}$ \\
& $(24,715)$ & $(318,570)$ & $(11,405)$ & $(299,681)$ & $(14,832)$ \\
\hline \hline
\end{tabular}

Table 6: Fiscal and monetary policy interactions. Normalised values of public debt over GDP across experiments. Absolute value of the simulation t-statistic of $H_{0}$ : "no difference between baseline and the experiment" in parentheses; $(* *)$ significant at $1 \%$ level, $\left({ }^{*}\right)$ significant at $5 \%$ level. $+\infty$ denotes cases of debt explosion (normalised value $>100$ ).

erably reduce the harm of "reckless" fiscal austerity rules $(S G P$ and $F C$ ) to the performance of the economy (see Tables 1-6). In particular, the average GDP growth rate becomes closer to the one observed with the benchmark fiscal policy (norule). However, even in presence of escape clauses, the fiscal rules are still responsible for higher GDP volatility, unemployment and occurrence of economic crises and they lead to higher sovereign debt to GDP ratio vis-à-vis the unconstrained fiscal policy case. These results confirm the crucial role of counter-cyclical fiscal policies supporting demand, and thus considerably dumping the costs of business cycle fluctuations.

Fiscal rules under the bond spread adjustment scenario. The evidence on the link between sovereign bonds rates and debt to GDP levels is inconclusive (De Grauwe and Ji, 2013). However, in some extreme cases, a reduction in public debt levels has been conjectured by some policymakers as a necessary condition for limiting sovereign risk premia and indirectly, via some imperfect mechanism, jumpstarting the economy. We implement this scenario (spread) for the five types of fiscal policies under study (cf. last column of Tables 1-6). Simulation results show that the introduction of the "spread" channel slightly worsens the performance of the economy in the baseline scenario as well as the ratio between sovereign debt and GDP. However, the results of our previous experiment are robust to the inclusion of a debt premium: the benchmark "free" fiscal rule still outperforms the four fiscal-discipline rules.

Alternative monetary policy rules. In the foregoing experiments the Central Bank has applied a standard Taylor rule which adjusts the baseline interest rate only to the inflation gap $\left(T R_{\pi}\right.$, see Eq. 4). In line with the recent monetary policy strategy of the Federal Reserve (Yellen, 2014), we now let the Central Bank follow a dual-mandate monetary policy $\left(T R_{\pi, U}\right)$ by including an adjustment to the unemployment gap $\left(\gamma_{U}>1\right)$, with a $5 \%$ unemployment rate target. When fiscal policy is unconstrained (norule) and the Central Bank commits to both price and output stabilisation, monetary policy positively affects only the short-run performance of the economy (see the third column of Tables 1-6). Indeed, GDP volatility, unemployment, likelihood of crises 
and the sovereign debt to GDP ratio are lower in the $T R_{\pi, U}$ vis-à-vis $T R_{\pi}$ scenarios, while the average GDP growth rates do not significantly increases. On the contrary, when fiscal rules are activated, the dual-mandate monetary policy strongly impacts on both the short- and longrun dynamics of the economy, contributing to alleviate the pains caused by fiscal-consolidation policies and helping to stabilise public finance. For every type of fiscal policy, the dual-mandate Taylor rule (slightly) increases the inflation rate, but in any case the average inflation rate is quite small (see Table 5). The presence of bank-based and balance-sheet transmission channels of monetary policy (see e.g. Bernanke et al., 1999; Boivin et al., 2010; Borio and Zhu, 2012) appear to be responsible for the better performance of the $T R_{\pi, U}$ rule over the $T R_{\pi}$ one. More precisely, this result is due to the interaction of the dual-mandate monetary policy with the Basel rule governing changes in credit supply. By linking credit availability to banks' equity, such macroprudential rule, we have already emphasised it, acts as an automatic de-stabiliser. During an economic downturn, banks' capital is weakened, which automatically reduces the credit available to firms. If bad-debt accumulates, the pro-cyclicality of the Basel rule can create a credit crunch, further expanding the economic crisis. In that case, reducing the Central Bank interest rate is not enough to relieve financial constraints. When using a dual-mandate monetary policy, during an expansion, interest rates increase as a response to low unemployment levels. With a higher profit margin, banks develop capital buffers against future shocks or reduce their bad debt. In the real sector high interest rates limit firms' borrowing and allows to contain the overheating of the economy as well as the formation of credit bubbles. When the downturn arrives, the interest rate goes down and loan losses increase. However, banks' capital buffers allow them to better resist the negative shocks, and provide more credit. By reducing the pro-cyclicality of the Basel macroprudential rule, the dual-mandate therefore compensates its destabilising effect and provides both banks and firms with a stronger financial record at the eve of an economic crisis.

In the last battery of policy experiments, we complement both types of Taylor rule policies by letting the Central Bank also act as a "lender of last resort" $\left(L L R_{\pi}\right.$ and $\left.L L R_{\pi, u}\right)$ : the Central Bank commits to buy an unlimited quantity of government bonds in order to keep the interest rate bounded to $1 \%$. This policy is supposed to reduce the financing costs of public debt. The results of these simulations are reported in the fourth and fifth columns of Tables 1-6. For the baseline fiscal policies, we find that, for both types of Taylor rules, the $L L R$ policy does not improve the performance of the economy, and it reduces the ratio between sovereign debt and GDP only when the Central Bank follows a dual-mandate Taylor rule. On the contrary, when the $S G P$ and $F C$ fiscal rules are activated, the $L L R$ policy positively affects the dynamics of the economy under a Taylor rule that pursues just price stabilisation $\left(L L R_{\pi}\right)$, whereas it contributes to increase the instability of the economy when the dual-mandate Taylor rule is in place $\left(L L R_{\pi, u}\right)$. For all the fiscal rules, "lender of last resort" policies appear to not increase the average inflation rate. At the same time, $L L R$ policies do not seem to help to stabilise the economy.

Taking stock of policy interactions. The simulation results show the strong interactions between different types of fiscal and monetary policies. The most evident and robust policy mix for stabilisation requires an unconstrained fiscal policy, where automatic stabilisers are 
free to dampen business cycles fluctuations, and a monetary policy targeting both price and output stability. Note that such policy combination achieves lower unemployment, lower output volatility and lower likelihood of crises without spurring the inflation rate or the sovereign debt to GDP ratio. Fiscal rules always depress the economy without improving the ratio between sovereign debt and GDP. The painful effects of fiscal rules are almost reduced by the introduction of escape clauses, which let the Government run deficits during recessions, and by a dual-mandate monetary policy, which is more effective in stabilising the economy than a "conservative" Taylor rule focused only on inflation stabilisation.

\subsection{Inequality and macroeconomic policies}

The policy experiments performed until now have been carried out for a given level of income inequality (the mark-ups of consumption-good firms fluctuate around the initial peg, cf. equations 20 and 21). However, a growing number of works have conjectured that the increasing levels of inequality have contributed to depress aggregate demand and to weigh down private indebtedness thus setting the stage for the Great Recession (Fitoussi and Saraceno, 2010; Kumhof and Rancière, 2010; Stiglitz, 2012). ${ }^{23}$ Such hypotheses were supported by the direct antecedent of this model (Dosi et al., 2013), where we found that a higher level of inequality increases the effects of fiscal policies. Given these premises, we explore how different levels of income inequality affect the dynamics of the banking sector and the results produced by the different mixes of fiscal and monetary policies spotlighted in the previous section.

The impact of the mark-up rate. Let us begin by analysing how our target variables evolve when we modify the income distribution under the benchmark scenario (norule, $T R_{\pi}$ ). Some of the results are reported in Figures 4 and 5. First, the size of the banking sector is negatively associated with the mark-up rate (Fig. 4 top left). Indeed, when the mark-up is low, firms have a reduced ability to finance their investment with their own accumulated profits and thus rely more on credit, boosting banks' profits and equity. This in turn increases the size of banks and the cost of banking crises.

Firm margins, by impacting on income inequality and then on aggregate demand, affect also the macroeconomic dynamics (cf. Fig. 5). If, on the one hand, the average GDP growth rate is stable for different levels of mark-up, on the other hand, the U-shape pattern displayed by GDP volatility, the unemployment rate and the likelihood of economic crisis reveal the existence of two "regimes". When mark-ups are low, firms' higher failure rates weaken the banking sector thus curbing the supply of credit. As a consequence, a higher proportion of financially constrained firms reduces production and investment leading to higher unemployment rates. When firms have high profit rates, they do not invest because expected demand is too low. This, - in line with the findings in Dosi et al. (2013) — spurs GDP volatility and unemployment.

Fiscal and monetary policy interactions. Why should the impact of fiscal rules change along with income distribution? As bailout costs are high when firms are credit constrained (see Figure 4), tighter limits on budget deficits can further depress aggregate demand thus amplifying the effects of financial constraints. Conversely, Dosi et al. (2013) have shown that when income

\footnotetext{
${ }^{23}$ For the empirical evidence about the long-run dynamics of income inequality, see Atkinson et al. (2011).
} 

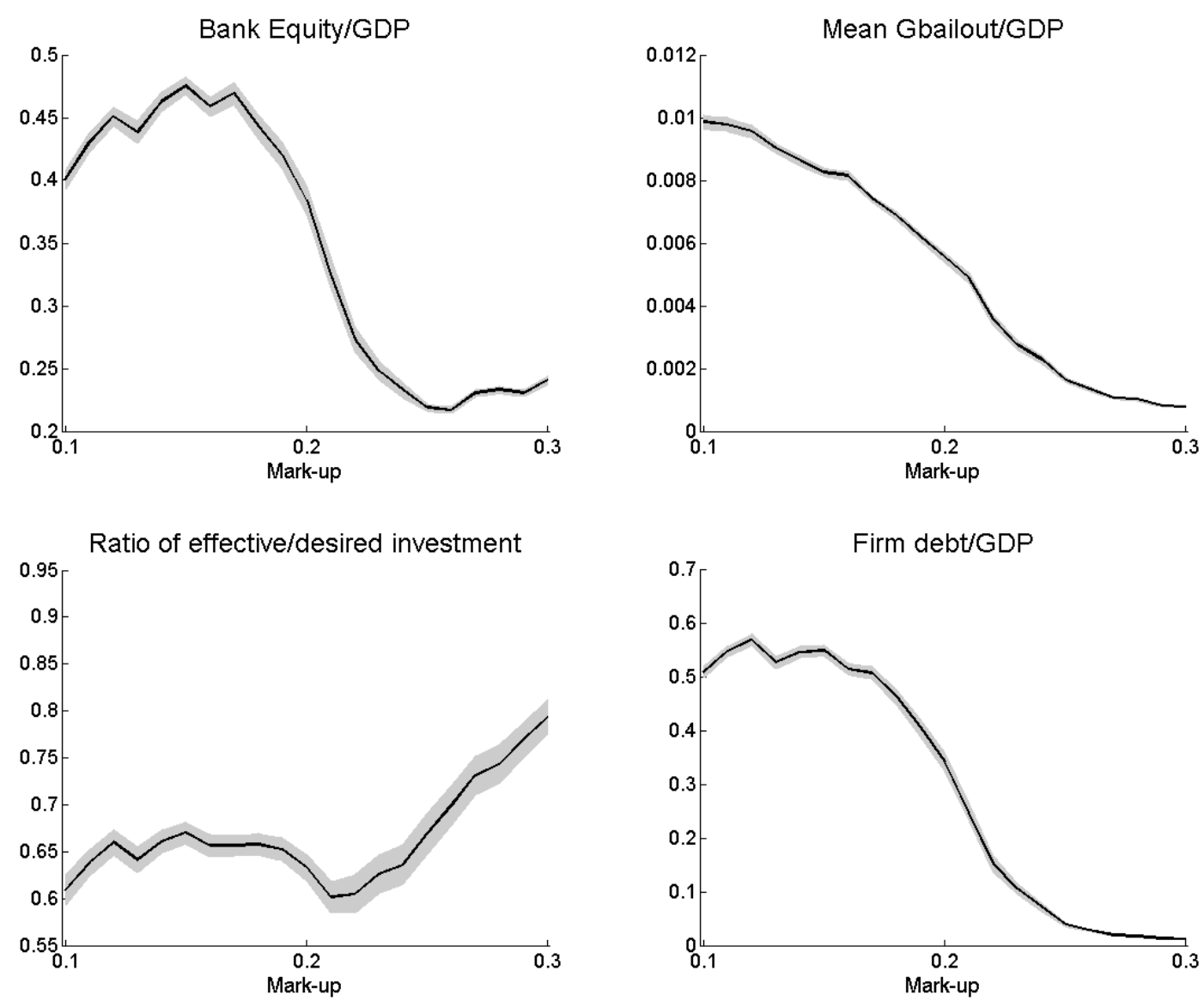

Figure 4: Income distribution and the banking sector. Confidence-interval bands are shown in a lighter colour and are computed as plus or minus twice Montecarlo standard errors 

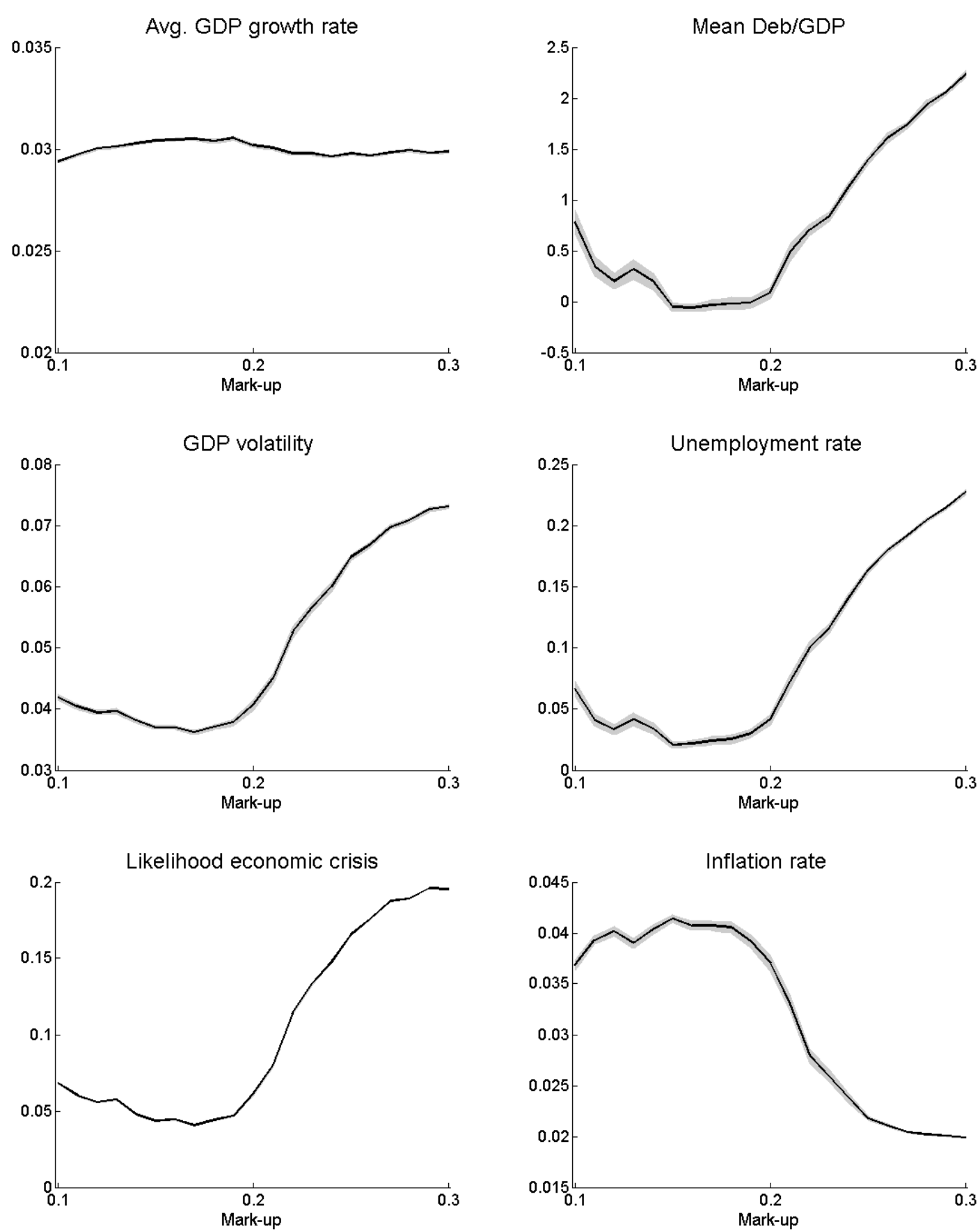

Figure 5: Income distribution and macroeconomic dynamics. Confidence-interval bands are shown in a lighter colour and are computed as plus or minus twice Montecarlo standard errors 

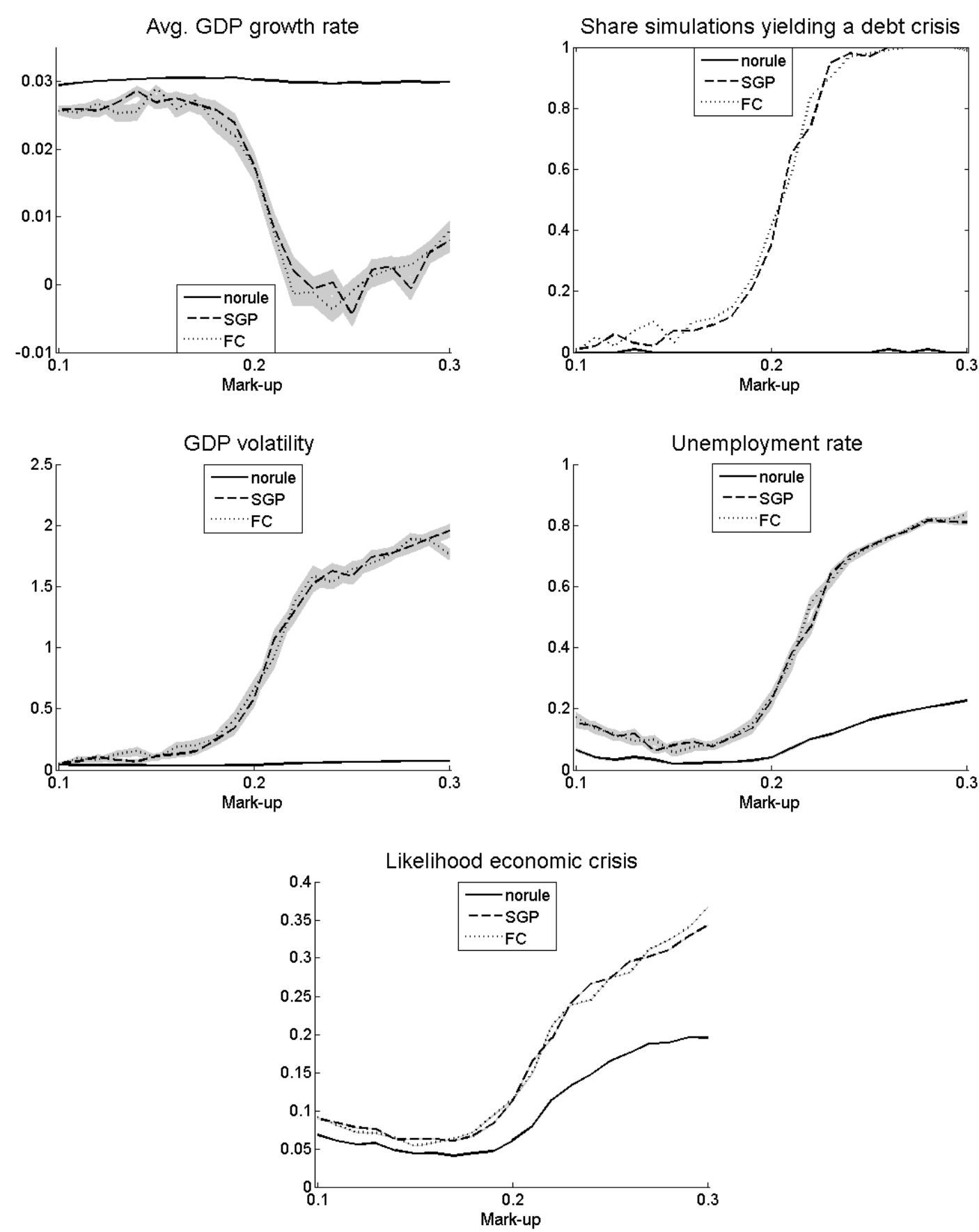

Figure 6: Fiscal rules without escape clauses. Confidence-interval bands are shown in a lighter colour and are computed as plus or minus twice Montecarlo standard errors 

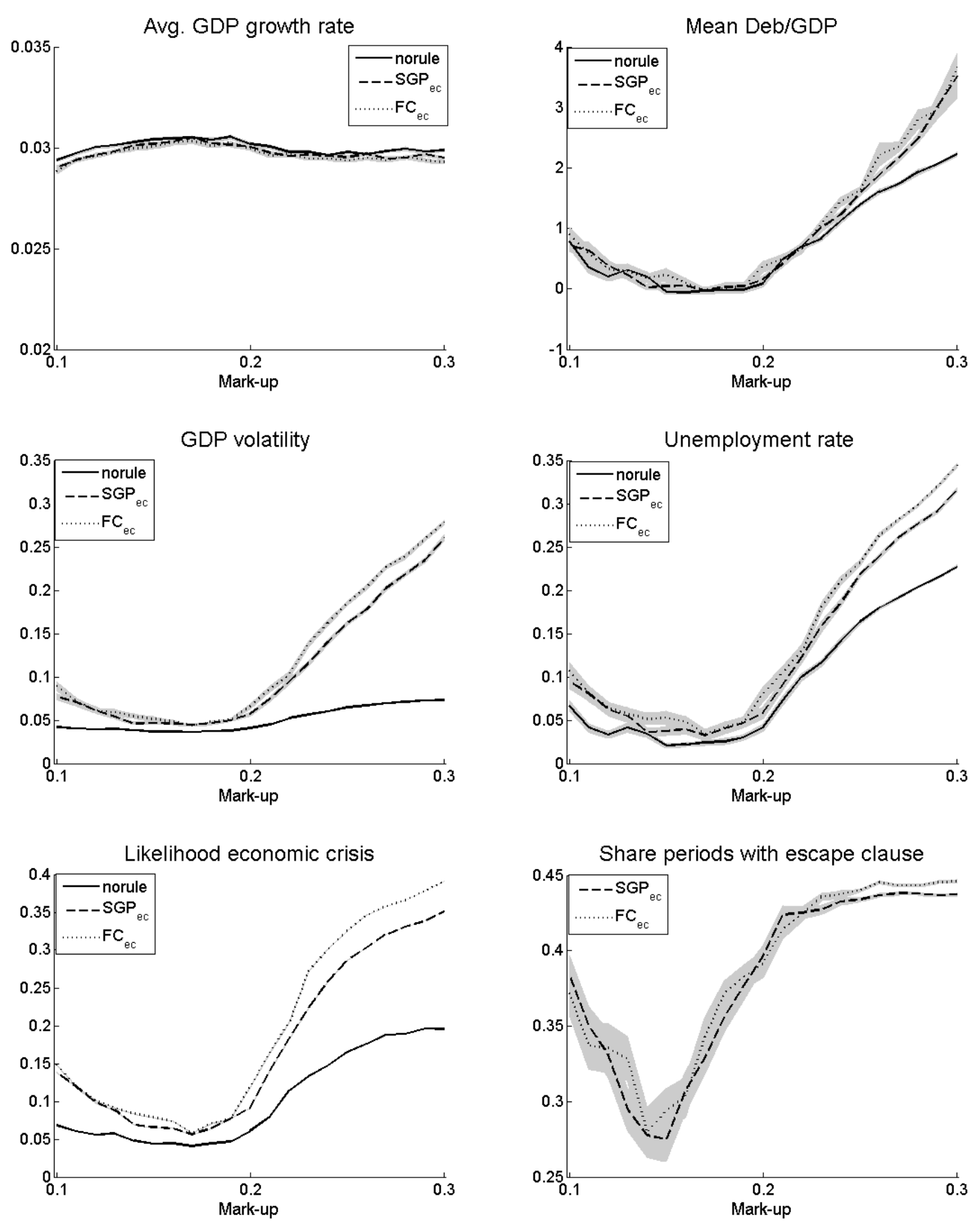

Figure 7: Fiscal rules with escape clauses. Confidence-interval bands are shown in a lighter colour and are computed as plus or minus twice Montecarlo standard errors 
inequality favours firms' higher margins, fiscal policy is more needed to sustain an (otherwise low) consumption demand. We test here the corollary, that fiscal discipline is more harmful as the income distribution is more biased towards profit. For every level of income inequality, we find that the SGP and FC fiscal rules increase the instability of the economy (see Figure 6) and they also inflate the ratio between public debt and GDP. Moreover, fiscal discipline appears to be more harmful as the income distribution becomes more biased towards profits. Indeed, even if in this regime firms have access to both internal and external financial resources, they do not invest for a lack of aggregate demand, which in turn reduces the average GDP growth rate and leads to the explosion of the public debt to GDP ratio. ${ }^{24}$ When the escape clauses are in place, they prevent the activation of fiscal rules up to $40 \%$ of the periods (Fig. 7, bottom right), thus reducing their negative impact on the dynamics of the economy. Nonetheless, in line with our previous results, the economy keeps on being more unstable and we keep on observing a perverse effect of fiscal rules on public debt. ${ }^{25}$

Let us conclude observing how monetary policy interacts with income inequality. The dualmandate Taylor rule performs much better than the "conservative" one for every level of inequality without leading to inflation spirals (cf. Figure 8). Which mechanisms are responsible for such dynamics? Figure 9 helps to understand the forces at play: with a dual-mandate Taylor rule, the banking sector performs better, as shown by a higher share of investment projects that are financed and implemented (Fig 9, top left), as well as by a lower rate of banking failures. Both results stem from higher bank profitability when interest rates are high. A negative feedback loop is indeed at play: lower unemployment pushes interest rates up, which strengthens bank's profitability, while tightening firms' constraints to invest. The increase of the interest rate cools down aggregate demand, while improving the net worth of the banks leading to higher supply of credit when the economy will experience a downturn. Finally, the results about the LLR policy observed in Section 4.1 are robust to changes in the income distribution.

\section{Concluding remarks}

Refining upon an incumbent agent-based model (Dosi et al., 2010, 2013) with both a real and a banking sector, in this paper we have studied the effects of alternative fiscal and monetary policies. The model robustly reproduces a wide ensemble of macro stylized facts and distributions of micro characteristics, but also banking crises, emerging from endogenous micro technological and demand shocks which propagate through the economy.

Simulation results reveal that the choice of the macroeconomic policy mix significantly affects the dynamics of the economy. If policy makers aim at stabilising both macroeconomic fundamentals (i.e. GDP growth, output volatility, unemployment and inflation rate) and public finances they should opt for an unconstrained fiscal policy coupled with a dual-mandate monetary policy. Jointly the two policies guarantee the lowest output fluctuations, unemployment rates, likelihood of economic crises, stabilising at the same time the inflation rate and

\footnotetext{
${ }^{24}$ In Figure 6 we report the share of simulations that end in a debt crisis, identified as an average public debt to GDP ratio above five.

${ }^{25}$ The results of our previous analysis are confirmed also in the bond spread adjustment scenario and are available from the authors upon request.
} 

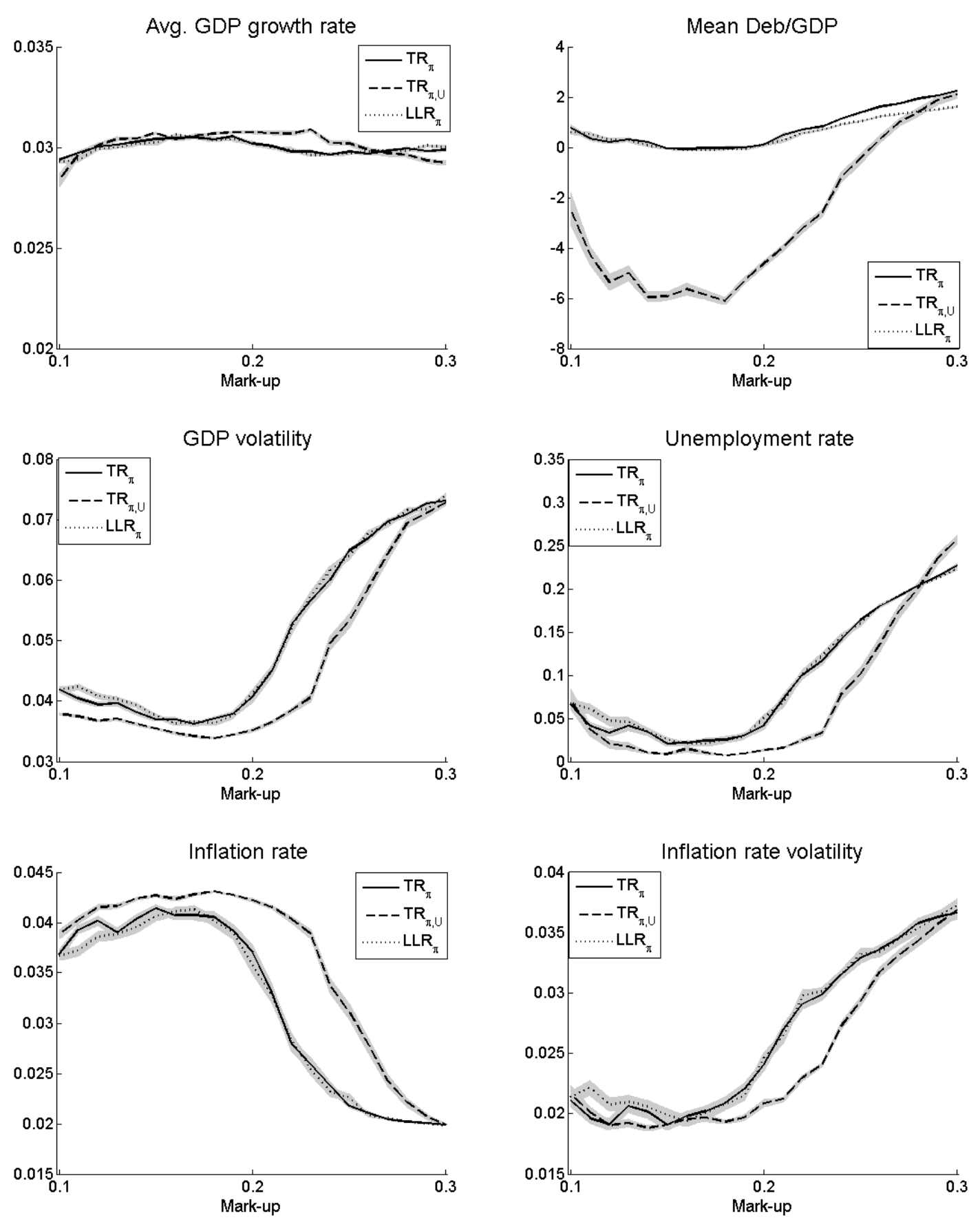

Figure 8: Monetary policy - macroeconomic dynamics. Confidence-interval bands are shown in a lighter colour and are computed as plus or minus twice Montecarlo standard errors 

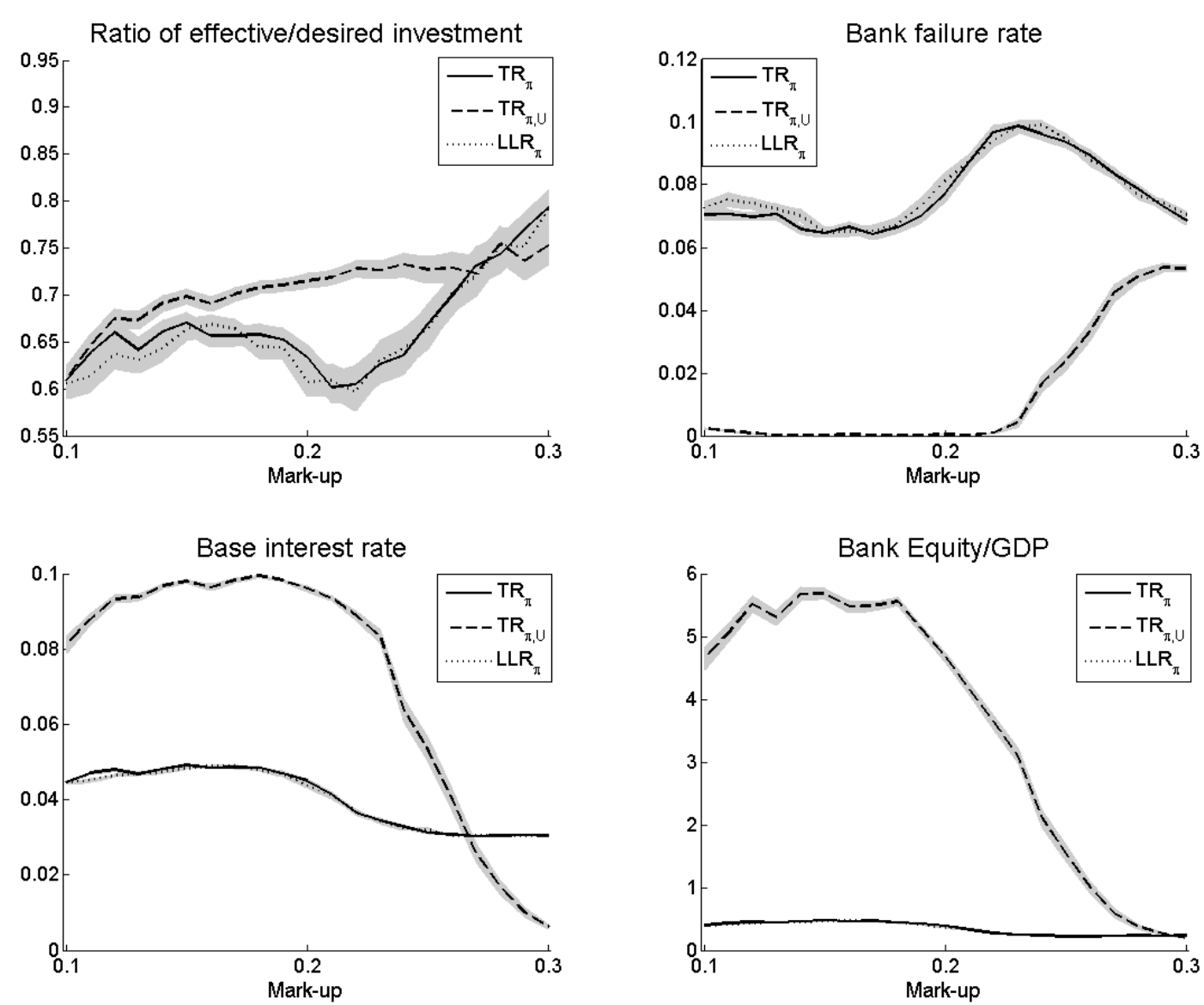

Figure 9: Monetary policy - the banking sector. Confidence-interval bands are shown in a lighter colour and are computed as plus or minus twice Montecarlo standard errors 
the sovereign debt to GDP ratio. We find that the introduction of fiscal rules mimicking the Stability and Growth Pact or the Fiscal Compact worsen the performance of the economy as well as public finances. In that, an extremely robust result shows that austerity policies appear to be self-defeating, indeed in line with a growing empirical evidence (De Grauwe and Ji, 2013). Concerning monetary policies, at the very least since the 2008 crisis, the validity of inflation targeting as a stabilising tool has been put into question, and alternative targets have been suggested (see e.g. Reichlin and Baldwin, 2013). In particular, the weak correlation between inflation and output may imply that inflation targeting is not enough to stabilise economic activity (Blanchard et al., 2013). Our model strengthens this finding. Indeed, the presence in the model of bank-based and balance-sheet transmission mechanisms of monetary policy implies that the depressive effects of fiscal-consolidation rules are exacerbated when the Central Bank follows a "conservative" Taylor rule focused only on inflation stabilisation. Instead, by reducing the pro-cyclicality of the Basel rule, a dual-mandate monetary policy compensates its destabilising effect and stabilises the economy. Finally, the impact of monetary and fiscal policy combinations is magnified by the level of income inequality in the economy. In particular, the recessionary effects of austerity fiscal rules are stronger when the income distribution is more biased toward profits.

Broadly speaking the economy typically displays two "regimes" (or more technically, two "phases") also discretely differentiating the effectiveness of different types of public policies. In one regime, characterised by high profits, lower demand, and low liquidity constraints to firms, monetary policies tend to be irrelevant to real dynamics and fiscal policies are paramount. Conversely, in the more "egalitarian", accelerator-driven regime of growth monetary policies may matter more especially on the down side: monetary restrictions bite. Throughout, Keynesian mechanisms of demand generation and transmission are always at work modulating all supplyside ("Schumpeterian") endogenous shocks. And in that negative aggregate demand shocks i.e. austerity measures - always bear a negative aggregate effect, always in the short-term and often also for the long-term rates of growth and unemployment.

The present model could be expanded according to several research routes. First, different ensembles of macroeconomic policies should be analysed considering e.g. the possible interactions between fiscal and monetary policies and Schumpeterian policies (building upon Dosi et al., 2010) and structural reforms (e.g. the Abenomics experiment, see Patrick, 2013). Finally, the impact of fiscal policies (for any type of monetary rule) could be better assessed by computing the size of the fiscal multipliers according to the state of the economy along the lines of Auerbach and Gorodnichenko (2012) and Ferraresi et al. (2013). 


\section{Acknowledgments}

We are grateful for helpful comments and discussions by Uwe Cantner, Tommaso Ciarli, Mario Cimoli, Herbert Dawid, Jean-Luc Gaffard, Co-Pierre Georg, Cars Hommes, Peter Howitt, Antoine Mandel, Joao Basilio Pereima, Gabriel Porcile, Marco Raberto, Xavier Ragot, Pier Paolo Saviotti, Oreste Tristani, Marco Valente, Murat Yıldızoğlu, and several participants at seminars at the University of Nice-Sophia Antipolis, Maastricht University, Sant'Anna School of Advanced Studies, and conferences at the Annual Meeting of the American Economic Association, Philadelphia, January 2014; the "OFCE-SKEMA-GREQAM Workshop on Agent-Based Macroeconomics", Sophia-Antipolis, November 2013; the "International Seminar on Advances in Economic Dynamics and Development: Economics and Complexity", UFPR, Curitiba, November 2013; the Bordeaux Workshop on Agent-Based Macroeconomics, Bordeaux, November 2013; the 25th EAEPE Annual Conference, Paris, November 2013; the Bundesbank/SAFE Conference, Frankfurt, October 2013; the SFC Workshops in Dijon, May 2013, and in Limerick, August 2013; the INET Workshop "Interlinkages and Systemic Risk", Ancona, July 2013; the Herbert Simon Society Conference, New York, April 2013; the seminar "Complexity, Innovation and TICs: Implications for Development Theory and Policy, ECLAC, Santiago, April 2013; the MAFIN 2012 Workshop on "Managing Financial Instability in Capitalist Economies", Genoa, September 2012; the 24th Villa Mondragone International Economic Seminar "Public Debt, Global Governance and Economic Dynamism", Rome, June 2012; the POLHIA International Conference "Rethinking Economic Policies in a Landscape of Heterogeneous Agents", Milan, October 2011; the 60th AFSE Conference, Paris, September 2011; the 17th Computing in Economics and Finance Conference, San Francisco, July 2011; the 28th Symposium on "Money, Banking and Finance", Reading, June 2011 and the 7th European Meeting on Applied Evolutionary Economics, Pisa, February 2011. All usual disclaimers apply. An earlier version of the paper circulated under the title "Heterogeneous Banks and Technical Change in an Evolutionary Model of Endogenous Growth and Fluctuations". The authors gratefully acknowledge the financial support of the Institute for New Economic Thinking (INET) grants \#220, "The Evolutionary Paths Toward the Financial Abyss and the Endogenous Spread of Financial Shocks into the Real Economy" and INO12-00039, "INET Taskforce in Macroeconomic Efficiency and Stability".

\section{References}

Adrian, T. and H. Shin (2010), "Financial Intermediaries and Monetary Economics", Staff Reports 398, Federal Reserve Bank of New York.

Akerlof, G. A. (2002), "Behavioral Macroeconomics and Macroeconomic Behavior", American Economic Review, 92: $411-433$.

Alesina, A. and S. Ardagna (2010), "Large Changes in Fiscal Policy: Taxes Versus Spending", NBER Chapters, in: Tax Policy and the Economy, 24: 35-68.

Alper, E. and L. Forni (2011), "Public Debt in Advanced Economies and its Spillover Effects on Long-Term Yields", Working Paper WP/11/210, International Monetary Fund.

Ascari, G., G. Fagiolo and A. Roventini (2013), "Fat-Tail Distributions and Business-Cycle Models", Macroeconomic Dynamics, doi:10.1017/S1365100513000473.

Ascari, G. and N. Rankin (2013), "The Effectiveness of Government Debt for Demand Management: Sensitivity to Monetary Policy Rules", Journal of Economic Dynamics and Control, 37: 1544-1566.

Ashraf, Q., B. Gershman and P. Howitt (2011), "Banks, Market Organization, and Macroeconomic Performance: an Agent-Based Computational Analysis", Working Paper 17102, National Bureau of Economic Research.

Atkinson, A. B., T. Piketty and E. Saez (2011), "Top Incomes in the Long Run of History", Journal of Economic Literature, 49: 3-71.

Auerbach, A. and Y. Gorodnichenko (2012), "Measuring the Output Responses to Fiscal Policy", American Economic Journal: Economic Policy, 4: 1-27.

Ausloos, M., J. Miskiewicz and M. Sanglier (2004), "The Durations of Recession and Prosperity: Does their Distribution Follow a Power or an Exponential Law?", Physica A: Statistical Mechanics and its Applications, 339: $548-558$.

Bartelsman, E. and M. Doms (2000), "Understanding Productivity: Lessons from Longitudinal Microdata", Journal of Economic Literature, 38: 569-94. 
Bartelsman, E. J., S. Scarpetta and F. Schivardi (2005), "Comparative Analysis of Firm Demographics and Survival: Micro-Level Evidence for the OECD Countries", Industrial and Corporate Change, 14: 365-391.

Battiston, S., D. Delli Gatti, M. Gallegati, B. Greenwald and J. Stiglitz (2012), "Liaisons Dangereuses: Increasing Connectivity, Risk Sharing, and Systemic Risk", Journal of Economic Dynamics and Control, 36: 1121-1141.

Baxter, M. and R. King (1999), "Measuring Business Cycles: Approximate Band-Pass Filter for Economic Time Series", The Review of Economics and Statistics, 81: 575-593.

Becker, B. and V. Ivashina (2014), "Cyclicality of Credit Supply: Firm Level Evidence", Journal of Monetary Economics, forthcoming.

Berger, A. N., A. K. Kashyap, J. M. Scalise, M. Gertler and B. M. Friedman (1995), "The Transformation of the US Banking Industry: What a Long, Strange Trip it's Been", Brookings Papers on Economic Activity, 1995: $55-218$.

Bernanke, B. S., M. Gertler and S. Gilchrist (1999), "The Financial Accelerator in a Quantitative Business Cycle Framework", in J. B. Taylor and M. Woodford, (eds.), Handbook of Macroeconomics, Elsevier, 1341-1393.

Bernanke, B. S. and F. S. Mishkin (1997), "Inflation Targeting: a New Framework for Monetary Policy?", Journal of Economic Perspectives, 11: 97-116.

Bikker, J. and P. Metzemakers (2005), "Bank Provisioning Behaviour and Procyclicality", International Financial Markets, Institutions and Money, 15: 141-157.

BIS (1999), "Capital Requirements and Bank Behaviour: the Impact of the Basle Accord", Working Papers 1, Bank for International Settlements.

Blanchard, O., G. Dell'Ariccia and P. Mauro (2010), "Rethinking Macroeconomic Policy", Journal of Money, Credit and Banking, 42: 199-215.

Blanchard, O. J., M. G. Dell'Ariccia and M. P. Mauro (2013), "Rethinking Macro Policy II: Getting Granular", Staff Discussion Note SDN/13/03, International Monetary Fund.

Blanchard, O. J. and D. Leigh (2013), "Growth Forecast Errors and Fiscal Multipliers", Working Paper 18779, National Bureau of Economic Research.

Boivin, J., M. T. Kiley and F. S. Mishkin (2010), "How Has the Monetary Transmission Mechanism Evolved Over Time?", in B. M. Friedman and M. Woodford, (eds.), Handbook of Monetary Economics, Elsevier, 369-422.

Borio, C. and H. Zhu (2012), "Capital Regulation, Risk-Taking and Monetary Policy: a Missing Link in the Transmission Mechanism?", Journal of Financial Stability, 8: 236-251.

Caprio, G. and D. Klingebiel (2002), "Episodes of Systemic and Borderline Banking Crises", in Managing the Real and Fiscal Effects of Banking Crises, World Bank Discussion Paper, 428, 31-49.

Caves, R. (1998), "Industrial Organization and New findings on the Turnover and Mobility of Firms", Journal of Economic Literature, 36: 1947-1982.

Christiano, L., M. Eichenbaum and S. Rebelo (2011), "When Is the Government Spending Multiplier Large?", Journal of Political Economy, 119: 78-121.

Ciarli, T., A. Lorentz, M. Savona and M. Valente (2010), "The Effect of Consumption and Production Structure on Growth and Distribution. A Micro to Macro Model", Metroeconomica, 61: 180-218.

Colander, D., P. Howitt, A. P. Kirman, A. Leijonhufvud and P. Mehrling (2008), "Beyond DSGE Models: Toward an Empirically Based Macroeconomics", American Economic Review, 98: 236-240.

Cottarelli, C. (2009), "The State of Public Finances: Outlook and Medium-Term Policies After the 2008 Crisis", Fiscal affairs department, International Monetary Fund.

Council of the European Union (2005), Annex II - Improving the Implementation of the Stability and Growth Pact, Council Report to the European Council.

Dawid, H., S. Gemkow, P. Harting, S. van der Hoog and M. Neugart (2014), "Agent-Based Macroeconomic Modeling and Policy Analysis: The Eurace@Unibi Model", in S.-H. Chen and M. Kaboudan, (eds.), Handbook on Computational Economics and Finance, Oxford University Press. 
De Grauwe, P. and Y. Ji (2013), "Self-Fulfilling Crises in the Eurozone: an Empirical Test", Journal of International Money and Finance, 34: 15-36.

De Masi, G., Y. Fujiwara, M. Gallegati, B. Greenwald and J. Stiglitz (2010), "An Analysis of the Japanese Credit Network", Evolutionary and Institutional Economics Review, 7: 209-232.

De Masi, G. and M. Gallegati (2007), Debt-Credit Economic Networks of Banks and Firms: the Italian Case, Springer: Milan.

Delli Gatti, D., S. Desiderio, E. Gaffeo, P. Cirillo and M. Gallegati (2011), Macroeconomics from the Bottom-Up, Springer: Milan.

Delli Gatti, D., C. Di Guilmi, E. Gaffeo, G. Giulioni, M. Gallegati and A. Palestrini (2005), "A New Approach to Business Fluctuations: Heterogeneous Interacting Agents, Scaling Laws and Financial Fragility", Journal of Economic Behavior and Organization, 56: 489-512.

Delli Gatti, D., M. Gallegati, B. Greenwald, A. Russo and J. Stiglitz (2010), "The Financial Accelerator in an Evolving Credit Network", Journal of Economic Dynamics \&S Control, 34: 1627-1650.

Doms, M. and T. Dunne (1998), "Capital Adjustment Patterns in Manufacturing Plants", Review Economic Dynamics, 1: 409-29.

Dosi, G. (2007), "Statistical Regularities in the Evolution of Industries. A Guide through some Evidence and Challenges for the Theory", in F. Malerba and S. Brusoni, (eds.), Perspectives on Innovation, Cambridge MA, Cambridge University Press.

Dosi, G. (2012), "Economic Coordination and Dynamics: Some Elements of an Alternative 'Evolutionary' Paradigm", in Economic Organization, Industrial Dynamics and Development, Selected Essays, Vol. 2, Edward Elgar Publishing, Cheltenham, UK, Northampton, MA, USA.

Dosi, G., G. Fagiolo, M. Napoletano and A. Roventini (2013), "Income Distribution, Credit and Fiscal Policies in an Agent-Based Keynesian Model", Journal of Economic Dynamics and Control, 37: 1598-1625.

Dosi, G., G. Fagiolo and A. Roventini (2006), "An Evolutionary Model of Endogenous Business Cycles", Computational Economics, 27: 3-34.

Dosi, G., G. Fagiolo and A. Roventini (2008), "The Microfoundations of Business Cycles: an Evolutionary, MultiAgent Model", Journal of Evolutionary Economics, 18: 413-432.

Dosi, G., G. Fagiolo and A. Roventini (2010), "Schumpeter Meeting Keynes, a Policy-Friendly Model of Endogenous Growth and Business Cycles", Journal of Economic Dynamics and Control, 34: 1748-1767.

Eggertsson, G. B. and P. Krugman (2012), "Debt, Deleveraging, and the Liquidity Trap: A Fisher-Minsky-Koo Approach", The Quarterly Journal of Economics, 127: 1469-1513.

Ennis, H. (2001), "On the Size Distribution of Banks", FRB Richmond Economic Quarterly, 87: 1-25.

Fagiolo, G., M. Napoletano and A. Roventini (2008), "Are Output Growth-Rate Distributions Fat-Tailed? Some Evidence from OECD Countries", Journal of Applied Econometrics, 23: 639-669.

Fagiolo, G. and A. Roventini (2012), "Macroeconomic Policy in Agent-Based and DSGE Models", Revue de l'OFCE, 124: 67-116.

Farmer, J. D. and D. Foley (2009), "The Economy Needs Agent-Based Modelling”, Nature, 460: 685-686.

Ferraresi, T., A. Roventini and G. Fagiolo (2013), "Fiscal Policies and Credit Regimes: A TVAR Approach", Working Paper 2013/03, Laboratory of Economics and Management (LEM).

Fitoussi, J. and F. Saraceno (2010), "Inequality and Macroeconomic Performance", Document de Travail 2010-13, OFCE, Paris.

Foos, D., L. Norden and M. Weber (2010), "Loan Growth and Riskiness of Banks", Journal of Banking and Finance, 34: 2929-2940.

Gaffard, J.-L. and M. Napoletano (eds.) (2012), Agent-Based Models and Economic Policy, volume 124 of Revue de l'OFCE. Debates and Policies, OFCE. 
Gai, P., A. Haldane and S. Kapadia (2011), "Complexity, Concentration and Contagion", Journal of Economic Dynamics \& Control, 58: 453-470.

Geanakoplos, J., R. Axtell, J. Farmer, P. Howitt, B. Conlee, J. Goldstein, M. Hendrey, N. Palmer and C.-Y. Yang (2012), "Getting at Systemic Risk via an Agent-Based Model of the Housing Market", Discussion Paper 1852, Cowles Foundation.

Giavazzi, F. and M. Pagano (1996), "Non-Keynesian Effects of Fiscal Policy Changes: International Evidence and the Swedish Experience", Working Paper 5332, National Bureau of Economic Research.

Greenwald, B. and J. Stiglitz (1993), "Financial Market Imperfections and Business Cycles", Quarterly Journal of Economics, 108: 77-114.

Guajardo, J., D. Leigh and A. Pescatori (2011), "Expansionary Austerity : New International Evidence", Working Paper Research Department WP/11/158, International Monetary Fund.

Howitt, P. (1992), "Interest Rate Control and Nonconvergence to Rational Expectations", Journal of Political Economy, 100: 776-800.

Hubbard, G. R. (1998), "Capital-Market Imperfections and Investment", Journal of Economic Literature, 36: 193-225.

Keynes, J. M. (1936), The General Theory of Employment, Interest, and Money, New York, Prometheus Books.

Kindleberger, C. P. (1986), The World in Depression: 1929-1939, volume 4, University of California Pr.

Kirman, A. P. (1992), "Whom or What Does the Representative Individual Represent?", Journal of Economic Perspectives, 6: 117-136.

Kirman, A. P. (2010a), Complex Economics. Individual and Collective Rationality, Routledge: London.

Kirman, A. P. (2010b), "The Economic Crisis is a Crisis for Economic Theory", CESifo Economic Studies, 56.

Krugman, P. (2013), "How the Case for Austerity Has Crumbled", The New York Review of Books, 6.

Kumhof, M. and R. Rancière (2010), "Inequality, Leverage and Crisis", Working Paper WP/10/268, International Monetary Fund.

Laeven, L. and F. Valencia (2008), "Systemic Banking Crises: A New Database", Working Paper WP/08/224, International Monetary Fund.

LeBaron, B. and L. Tesfatsion (2008), "Modeling Macroeconomies as Open-Ended Dynamic Systems of Interacting Agents", American Economic Review, 98: 246-250.

Leith, C. and S. Wren-Lewis (2000), "Interactions Between Monetary and Fiscal Policy Rules", The Economic Journal, 110: 93-108.

Lengnick, M. (2013), "Agent-Based Macroeconomics: A Baseline Model", Journal of Economic Behavior E Organization, 86: $102-120$.

Lof, M. and T. Malinen (2013), "Does Sovereign Debt Weaken Economic Growth? A Panel VAR Analysis.", MPRA Paper 52039, University of Helsinki, HECER.

Mandel, A., C. Jaeger, S. Fuerst, W. Lass, D. Lincke, F. Meissner, F. Pablo-Marti, S. Wolf et al. (2010), "AgentBased Dynamics in Disaggregated Growth Models", CES Working Paper 2010.77, Université Paris 1 Panthéon Sorbonne.

McKay, A. and R. Reis (2013), "The Role of Automatic Stabilizers in the U.S. Business Cycle", Working Paper 19000, National Bureau of Economic Research.

Mendoza, E. and M. Terrones (2012), "An Anatomy of Credit Booms and their Demise", Working Paper 18379, National Bureau of Economic Research.

Modigliani, F. and M. Miller (1958), "The Cost of Capital, Corporation Finance and the Theory of Investment", American Economic Review, 48: 261-97.

Myers, S. (1984), "The Capital Structure Puzzle", The Journal of Finance, 39: 575-592. 
Napoletano, M., A. Roventini and S. Sapio (2006), "Are Business Cycles All Alike? A Bandpass Filter Analysis of the Italian and US Cycles", Rivista Italiana degli Economisti, 1: 87-118.

Nelson, R. R. and S. G. Winter (1982), An Evolutionary Theory of Economic Change, Cambridge, The Belknap Press of Harvard University Press.

Ng, S. and J. H. Wright (2013), "Facts and Challenges from the Great Recession for Forecasting and Macroeconomic Modeling", Journal of Economic Literature, 51: 1120-1154.

Olivero, M. P. (2010), "Market Power in Banking, Countercyclical Margins and the International Transmission of Business Cycles", Journal of International Economics, 80: 292-301.

Patrick, H. (2013), “Abenomics: Japan's New Economic Policy Package”, Occasional Paper Series 62, Center on Japanese Economy and Business, Columbia University.

Phelps, E. S. and S. G. Winter (1970), "Optimal Price Policy under Atomistic Competition", in E. S. Phelps, (ed.), Microeconomic Foundations of Employment and Inflation Theory, New York, Norton.

Poterba, J. M. (1995), "State Responses to Fiscal Crisis: The Effects of Budgetary Institutions and Politics", Working Paper 4375, National Bureau of Economic Research.

Presbitero, A. F. (2006), "The Debt-Growth Nexus: a Dynamic Panel Data Estimation", Rivista Italiana degli Economisti, 11: 417-462.

Raberto, M., S. Cincotti and A. Teglio (2014), "Fiscal Consolidation and Sovereign Debt Risk in Balance-Sheet Recessions: an Agent-Based Approach", in L. Mamica and P. Tridico, (eds.), Economic Policy and the Financial Crisis, Routledge.

Raberto, M., A. Teglio and S. Cincotti (2012), "Debt, Deleveraging and Business Cycles: An Agent-Based Perspective", Economics-The Open-Access, Open-Assessment E-Journal, 6: 2011-31.

Reichlin, L. and R. Baldwin (eds.) (2013), Is Inflation Targeting Dead? Central Banking After the Crisis, Centre for Economic Policy Research (CEPR).

Reinhart, C. and K. Rogoff (2009), "The Aftermath of Financial Crises", Working Paper 14656, National Bureau of Economic Research.

Riccetti, L., A. Russo and M. Gallegati (2013), "Leveraged Network-Based Financial Accelerator", Journal of Economic Dynamics and Control, 37: 1626-1640.

Rosser, B. J. (2011), Complex Evolutionary Dynamics in Urban-Regional and Ecologic-Economic Systems: From Catastrophe to Chaos and Beyond, Springer: New York.

Rotemberg, J. (2008), "Behavioral Aspects of Price Setting, and Their Policy Implications", Working Paper 13754, National Bureau of Economic Research.

Rotemberg, J. and M. Woodford (1999), "The Cyclical Behavior of Prices and Costs", in J. Taylor and M. Woodford, (eds.), Handbook of Macroeconomics, Elsevier, 1051-1135.

Salle, I., M. Yıldızoğlu and M.-A. Sénégas (2013), "Inflation Targeting in a Learning Economy: an ABM Perspective", Economic Modelling, 34: 114 - 128.

Saviotti, P. and A. Pyka (2008), "Product Variety, Competition and Economic Growth", Journal of Evolutionary Economics, 18: 323-347.

Schaechter, A., T. Kinda, N. Budina and A. Weber (2012), "Fiscal Rules in Response to the Crisis-Toward the 'Next-Generation' Rules: A New Dataset", Working Paper WP/12/187, International Monetary Fund.

Seppecher, P. (2012), "Flexibility of Wages and Macroeconomic Instability in an Agent-Based Computational Model with Endogenous Money", Macroeconomic Dynamics, 16: 284-297.

Solow, R. M. (2005), "Rethinking Fiscal Policy", Oxford Review of Economic Policy, 21: 509-514.

Solow, R. M. (2008), "The State of Macroeconomics", Journal of Economic Perspectives, 22: 243-246.

Stiglitz, J. (2012), The Price of Inequality: How Today's Divided Society Endangers Our Future, W. W. Norton \& Company. 
Stiglitz, J. and A. Weiss (1981), "Credit Rationing in Markets with Imperfect Information", The American Economic Review, 71: 393-410.

Stock, J. and M. Watson (1999), "Business Cycle Fluctuations in U.S. Macroeconomic Time Series", in J. Taylor and M. Woodford, (eds.), Handbook of Macroeconomics, Elsevier, 3-64.

Tasca, P. and S. Battiston (2011), "Diversification and Financial Stability", CCSS Working Paper Series CCSS11-001, ETH Zurich.

Taylor, J. (1993), "Discretion versus Policy Rules in Practice", Carnegie-Rochester Series on Public Policy, 39 : $195-214$.

Tesfatsion, L. (2001), "Guest Editorial Agent-Based Modeling of Evolutionary Economic Systems", IEEE Transactions on Evolutionary Computation, 5: 437-441.

Tesfatsion, L. and K. L. Judd (eds.) (2006), Handbook of Computational Economics, Volume 2: Agent-based Computational Economics, North-Holland.

Verspagen, B. (2002), "Evolutionary Macroeconomics: a Synthesis Between Neo-Schumpeterian and PostKeynesian Lines of Thought", The Electronic Journal of Evolutionary Modeling and Economic Dynamics, 1007, http://www.e-jemed.org/1007/index.php.

Walsh, C. (2009), "Using Monetary Policy to Stabilize Economic Activity", Proceedings - Economic Policy Symposium - Jackson Hole, Federal Reserve Bank of Kansas City, 2009: 245-296.

Woodford, M. (2011), "Simple Analytics of the Government Expenditure Multiplier", American Economic Journal: Macroeconomics, 3: 1-35.

Wright, I. (2005), "The Duration of Recessions Follows an Exponential not a Power Law", Physica A: Statistical Mechanics and its Applications, 345: 608-610.

Yellen, J. (2014), Monetary Policy Report to the Congress, Board of Governors of the Federal Reserve System. 


\section{A The model: capital- and consumption-good industries}

In this appendix we present the full formal structure of the real side of the model discussed in Section 2. We start with the equations characterising search processes and the determination of production and prices in the capital-good sector. Next we turn to present the equations related to the determination of production, investment, prices and profits in the consumption-good sector.

\section{A.1 The capital-good industry, complements}

Capital-good firms' technology is defined by $A_{i}^{\tau}$, the labour productivity in the consumptiongood sector of the machine tool produced by firm $i$ and $B_{i}^{\tau}$, the labour productivity of firm $i$ itself, with $\tau$ the technology vintage. ${ }^{26}$ Firms define their price by applying a fixed mark-up $\left(\mu_{1}>0\right)$ on their unit cost of production defined by the nominal wage $w_{t}$ and productivity level $\left(c_{i, t}=\frac{w_{t}}{B_{i}^{\tau}}\right)$. Capital-good firms can increase both their process $\left(B_{i}^{\tau}\right)$ and product $\left(A_{i}^{\tau}\right)$ technology levels via (costly) innovation and imitation. Indeed, R\&D expenditures, defined in each period as a fraction $\nu \in[0,1]$ of past sales are split between both activities according to the parameter $\xi \in[0,1]$.

The innovation process has two steps: first a random draw from a Bernoulli distribution of parameter $\theta_{i, t}^{i n}=1-e^{-\zeta_{1} I N_{i, t}}$ determines whether firm $i$ innovates or not, with $\zeta_{1} \leqslant 1$. Note that higher amounts of R\&D expenditures allocated to innovation $\left(I N_{i, t}\right)$ increase the probability to innovate. If an innovation occurs, the firm draws the new technology whose labour productivity levels $\left(A_{i}^{i n}, B_{i}^{i n}\right)$ are given by:

$$
\begin{aligned}
& A_{i, t}^{i n}=A_{i, t}\left(1+x_{i, t}^{A}\right) \\
& B_{i, t}^{i n}=B_{i, t}\left(1+x_{i, t}^{B}\right),
\end{aligned}
$$

where $x_{i}^{A}$ and $x_{i}^{B}$ are two independent draws from a $\operatorname{Beta}\left(\alpha_{1}, \beta_{1}\right)$ distribution over the support $\left[\underline{x}_{1}, \bar{x}_{1}\right]^{27}$ with $\underline{x}_{1}$ belonging to the interval $[-1,0]$ and $\bar{x}_{1}$ to $[0,1]$. The imitation process is similarly performed in two steps. A Bernoulli draw $\left(\theta_{i, t}^{i m}=1-e^{-\zeta_{2} I M_{i, t}}\right)$ defines access to imitation given the imitation expenditures $I M_{i, t}$, with $0<\zeta_{2} \leqslant 1$. In the second stage, a competitor technology is imitated, based on an imitation probability which decreases in the technological distance (computed adopting Euclidean metrics) between every pair of firms. Note that the innovative and imitation processes are not always successful as the newly discovered technology might not outperform firm $i$ 's current vintage. The comparison between the new and incumbent generations of machines is made taking into account both price and efficiency. The selected machine is chosen as follows:

$$
\min \left[p_{i, t}^{h}+b c^{h}\left(A_{i, t}^{h}\right)\right], \quad h=\tau, i n, i m,
$$

where $b$ is a positive payback period parameter for consumption-good firms (see Eq. 19 below). Next, capital-good firms advertise their machine's price and productivity by sending a "brochure" to potential customers (both to historical $-H C_{i, t^{-}}$clients and to a random sample of potential new customers $-N C_{i, t},{ }^{28}$ ) consumption-good firms thus have access to imperfect information about the available machines.

\footnotetext{
${ }^{26}$ Consumption-good firms' unit labour cost associated with the machine of vintage $\tau$ is $c\left(A_{i}^{\tau}, t\right)=\frac{w(t)}{A_{i}^{\tau}}$.

${ }^{27}$ The shape and support of the Beta distribution define the extent of technological opportunities available to firms. The role of "Schumpeterian" technology policies impacting these opportunities has been studied in depth in Dosi et al. (2010).

${ }^{28}$ The random sample is proportional to the size of $H C_{i, t}$, i.e., $N C_{i, t}=\varpi H C_{i, t}$, with $0<\varpi<1$.
} 


\section{A.2 The consumption-good industry, complements}

Consumption-good firms produce a homogeneous good using two types of inputs (labor and capital) with constant returns to scale. The desired level of production $Q_{j}^{d}$ depends on adaptive demand expectations $D_{j}^{e}=f\left(D_{j, t-1}, D_{, t-2}, \ldots, D_{j, t-h}\right)$, desired inventories $\left(N_{j}^{d}\right)$ and firm $j$ 's stock of inventories $\left(N_{j}\right)$ :

$$
Q_{j, t}^{d}=D_{j, t}^{e}+N_{j, t}^{d}-N_{j, t-1}
$$

with $N_{j, t}^{d}=\iota D_{j, t}^{e}, \iota \in[0,1]$.

Consumption-good firms' production is limited by their capital stock $\left(K_{j, t}\right)$. Given the desired level of production firms evaluate their desired capital stock $\left(K_{j, t}^{d}\right)$, which, if higher than their current one, calls for desired expansionary investment $\left(E I_{j, t}^{d}\right):^{29}$

$$
E I_{j, t}^{d}=K_{j, t}^{d}-K_{j, t} .
$$

Each firms' stock of capital is made of a set of different vintages of machines $\Xi_{j, t}$, with heterogeneous productivity. Machines with technology $A_{i}^{\tau} \in \Xi_{j, t}$ are scrapped according to a payback period routine which considers their technology obsolescence and new machines' prices:

$$
R S_{j, t}=\left\{A_{i}^{\tau} \in \Xi_{j, t}: \frac{p_{t}^{*}}{c\left(A_{i, \tau}, t\right)-c_{t}^{*}} \leq b\right\},
$$

where $p^{*}$ and $c^{*}$ are the price of and unit cost of production upon the new machines. Total replacement investment is then computed at firm level as the number of scrapped machines satisfying Equation 19, and those with age above $\eta$ periods, $\eta>0$. Firms compute the average productivity of their current capital stock $\left(\pi_{j, t}\right)$, the unit cost of production $\left(c_{j, t}\right)$, and set prices by applying a variable mark-up $\left(\mu_{j, t}\right)$ on unit costs of production:

$$
p_{j, t}=\left(1+\mu_{j, t}\right) c_{j, t} .
$$

Mark-up variations are linked to changes in firms' market shares $\left(f_{j}\right):^{30}$

$$
\mu_{j, t}=\mu_{j, t-1}\left(1+v \frac{f_{j, t-1}-f_{j, t-2}}{f_{j, t-2}}\right),
$$

with $0 \leqslant v \leqslant 1$.

Consumers have imperfect information regarding the final product (see Rotemberg, 2008, for a survey on consumers' imperfect price knowledge) which prevents them from instantaneously switching to the most competitive producer. Still, a firm's competitiveness $\left(E_{j, t}\right)$ directly relates to its price, but also to the amount of unfilled demand $\left(l_{j, t}\right)$ inherited from the previous period:

$$
E_{j, t}=-\omega_{1} p_{j, t}-\omega_{2} l_{j, t}
$$

where $\omega_{1,2}>0 .{ }^{31}$ At the aggregate level, the average competitiveness of the consumption-good sector is computed as the competitiveness of each consumption-good firm weighted by its past

\footnotetext{
${ }^{29}$ Following the empirical literature on firm investment patterns (e.g. Doms and Dunne, 1998), firms' expansion in production capacity is limited by a fixed maximum threshold. Moreover, as described in Section 2.2, creditconstrained firms' effective investment does not reach the desired level.

${ }^{30}$ Such assumption relates to "customer market" models as originally described by Phelps and Winter (1970).

${ }^{31}$ Such unfilled demand is due to the difference between expected and actual demand. Firms set their production according to the expected demand. If a firms is not able to satisfy the actual demand, its competitiveness is accordingly reduced. On the contrary, if expected demand is higher than actual one, inventories accumulate.
} 
market share $\left(f_{j}\right)$ :

$$
\bar{E}_{t}=\sum_{j=1}^{F_{2}} E_{j, t} f_{j, t-1} .
$$

Following a "quasi" replicator dynamics, firms' competitiveness drive the dynamics of their market shares:

$$
f_{j, t}=f_{j, t-1}\left(1+\chi \frac{E_{j, t}-\bar{E}_{t}}{\bar{E}_{t}}\right)
$$

\begin{tabular}{|c|c|c|}
\hline Description & Symbol & Value \\
\hline \multicolumn{3}{|l|}{ Benchmark parameters } \\
\hline Montecarlo replications & $M C$ & 100 \\
\hline Time sample & $T$ & 600 \\
\hline Number of firms in capital-good industry & $F_{1}$ & 50 \\
\hline Number of firms in consumption-good industry & $F_{2}$ & 200 \\
\hline Number of banks & $B$ & 10 \\
\hline Capital-good firms' mark-up & $\mu_{1}$ & 0.04 \\
\hline Consumption-good firm initial mark-up & $\bar{\mu}_{0}$ & 0.20 \\
\hline Uniform distribution supports & {$\left[\phi_{1}, \phi_{2}\right]$} & {$[0.10,0.90]$} \\
\hline Wage setting $\triangle \overline{A B}$ weight & $\psi_{1}$ & 1 \\
\hline Wage setting $\Delta c p i$ weight & $\psi_{2}$ & 0.05 \\
\hline Wage setting $\Delta U$ weight & $\psi_{3}$ & 0.05 \\
\hline Banks deposits interest rate & $r^{D}$ & 0 \\
\hline Bond interest rate mark-down & $\mu^{\text {bonds }}$ & -0.33 \\
\hline Loan interest rate mark-up & $\mu^{d e b}$ & 0.30 \\
\hline Bank capital adequacy rate & $\tau^{b}$ & 0.08 \\
\hline Shape parameter of bank client distribution & pareto $_{a}$ & 0.08 \\
\hline Scaling parameter for interest rate cost & $k_{\text {const }}$ & 0.10 \\
\hline Capital buffer adjustment parameter & $\beta$ & 1 \\
\hline R\&D investment propensity & $\nu$ & 0.04 \\
\hline R\&D allocation to innovative search & $\xi$ & 0.50 \\
\hline Firm search capabilities parameters & $\zeta_{1,2}$ & 0.30 \\
\hline Beta distribution parameters (innovation process) & $\left(\alpha_{1}, \beta_{1}\right)$ & $(3,3)$ \\
\hline Beta distribution support (innovation process) & {$\left[\underline{x}_{1}, \bar{x}_{1}\right]$} & {$[-0.15,0.15]$} \\
\hline New customer sample parameter & $\varpi$ & 0.50 \\
\hline Desired inventories & $\iota$ & 0.10 \\
\hline "Physical" scrapping age & $\eta$ & 20 \\
\hline Payback period & $b$ & 3 \\
\hline Mark-up coefficient & $v$ & 0.04 \\
\hline Consumption-good firm initial mark-up & $\bar{\mu}_{0}$ & 0.20 \\
\hline Competitiveness weights & $\omega_{1,2}$ & 1 \\
\hline \multicolumn{3}{|l|}{ Policy experiment parameters } \\
\hline Inflation adjustment parameter $\left(T R_{\pi}, T R_{\pi, U}\right)$ & $\gamma_{\pi}$ & 1.10 \\
\hline Unemployment adjustment parameter $\left(T R_{\pi, U}\right)$ & $\gamma_{U}$ & 1.10 \\
\hline Target interest rate & $r^{T}$ & 0.025 \\
\hline Target inflation rate & $\pi^{T}$ & 0.02 \\
\hline Tax rate & $\operatorname{tr}$ & 0.10 \\
\hline Unemployment subsidy rate & $\varphi$ & 0.40 \\
\hline Fiscal rule max deficit to GDP $(S G P, F C)$ & def $f_{\text {rule }}$ & 0.03 \\
\hline Fixed interest rate on bonds $(L L R)$ & $\bar{r}_{\text {bonds }}$ & 0.01 \\
\hline
\end{tabular}

with $\chi>0$.

Table 7: Parameters 